\title{
The Effects of Temperament, Social Support and Emotion Regulation on the Positive Psychological Capital of Middle School Students
}

Ara Choi, Sook Lee

Department of Family Environment \& Welfare, Chonnam National University, Gwangju, Korea

\author{
중학생의 기질, 사회적지지 및 정서조절능력이 긍정심리자본에 미치는 영향 \\ 최아라, 이숙 \\ 전남대학교 생활환경복지학과
}

Objective: This study examined the influences of general characteristics, temperament, social support, and emotional regulation on the positive psychological capital of adolescents. The data were collected from 672 middle school students living in Gwangju.

Methods: Data were analyzed using Pearson correlation analyses and hierarchical regression analyses.

Results: Temperament best explained positive psychological capital. In terms of individual factors, self-emotion regulation had the greatest effect on positive psychological capital, followed by friend support, persistence temperament, others emotion regulation, academic achievement, harm avoidance temperament, gender, and family support, in that order.

Conclusion: The results for the effects of temperament, social support and emotion regulation on adolescent's positive psychological capital highlights the important roles played by the temperament, social support, and emotion regulation in improving an adolescent's positive psychological capital. The study contributes to the literature by proving fundamental insights into an adolescent's psychological strengths and higher quality of life.

Keywords: temperament, social support, emotion regulation, positive psychological capital

\begin{abstract}
서론
최근 급증하고 있는 청소년의 학교폭력, 스마트폰과 인터넷 중독, 집단 따돌림, 비행문제, 자살과 같은 현상은 이제 청소년 개인 차원의 문제가 아니라 사회적 문제로 대두되고 있다. 이 러한 청소년문제의 발생 빈도가 점차 잦아지고 그 유형이 다 양화된다는데 그 심각성을 찾을 수 있다.
\end{abstract}

Corresponding Author: Sook Lee, Department of Family Environment \& Welfare, Chonnam National University, 77, Yongbong-ro, Buk-gu, Gwangju 61186, Korea.

E-mail: sookleej@hanmail.net
Statistics Korea (2015)에 따르면 청소년의 $35.4 \%$ 가 스트레 스를 인지하고 있는 것으로 나타났으며, 중고생의 $34 \%$ 가 우 울감을 경험하는 것으로 나타나 부적응문제 뿐만 아니라 정신 건강 역시 청소년기의 심각한 문제로 대두되고 있다. 이러한 청소년기의 문제는 청소년기 이후 성인기에까지 영향을 줄 수 있기 때문에 청소년기의 정서적 · 행동적 문제에 대한 올바른 이해와 초기 중재를 위한 사회적 노력이 필요하다.

(C)The Korean Association of Child Studies

This is an Open Access article distributed under the terms of the Creative Commons Attribution Non-Commercial License (http:// creativecommons.org/licenses/by-nc/4.0) which permits unrestricted noncommercial use, distribution, and reproduction in any medium, provided the original work is properly cited. 
청소년기는 아동기에서 성인기에 이르는 과도기로서, 사춘 기의 급속한 신체변화가 심리적 변화를 초래하여 정서성과 민 감성이 높을 뿐만 아니라 사회적 환경의 영향을 쉽게 받게 되 어 불안정한 상태에 처할 수 있다. 사춘기 청소년들은 부모와 의 갈등, 또래집단에의 몰두, 정서적 불안 등 다양한 변화를 경 험하며(M. H. Lee \& Shin, 2015), 정신적인 면에서도 아동기와 달리 자의식이 발달하고 욕구좌절이나 사회적 부적응으로 인 한 반항적 태도가 나타나기도 한다(K. S. Lee, 2015). 그러나 사 춘기에 있는 모든 학생들이 문제행동을 보이는 것은 아니다. 발달적 시기와 주어진 환경이 비슷하더라도 이를 어떻게 느끼 고 판단하느냐에 따라 그들의 반응양상이나 행동은 다르게 나 타난다. 즉, 주어진 환경에 대해 개인이 긍정적인 심리적 강점 을 사용하여 진취적인 사고와 행동을 함으로써 긍정적 결과를 도출하는데(K. Y. Lee \& Song, 2010), 이 때 긍정적인 심리적 강 점을 ‘긍정심리자본’으로 볼 수 있다.

긍정심리자본(positive psychological capital)은 긍정심리학의 창시자인 Seligman에 의해 시작되었는데, Seligman (1998)에 따르면 개인의 긍정적 심리상태는 정신적 건강과 신체적 건강 뿐 아니라 직업이나 학업에서도 높은 성과를 달성하게 한다 고 하였다. 이후 Luthans (2002)가 개인의 긍정적 심리에 관한 이론을 더 발전시켜 자기효능감, 희망, 낙관성, 복원력 등 네 가지 개념들이 성취와 성공을 향한 개인의 긍정적인 인지상 태라는 공통점을 발견하였으며, 그 후 네 가지 구성개념을 통 합한 상위구성개념으로 긍정심리자본의 개념을 사용하였다 (F. Luthans \& Youssef, 2004; F. Luthans, Avey, Avolio, \& Norman, 2007). 즉, 긍정심리자본은 일상적 또는 도전적인 상황에서 자 아개념(self-concept)을 긍정적으로 이끄는 심리적 매커니즘 (Martin, Kuiper, Olinger, \& Dance, 1993)으로 자기효능감, 희 망, 복원력, 낙관성 등의 다차원적인 개념으로 구성된 개인의 긍정적인 심리상태를 의미한다(Luthans et al., 2007). Luthans 등(2007)은 긍정심리자본의 자기효능감, 희망, 낙관성, 복원 력 등의 개념들이 개별적으로 이해되기 보다는 통합적인 심리 적 자원으로 이해될 때 개별 변수들의 상승작용이 더 잘 이해 될 수 있으며(Y. K. Cho, 2011), 개별 변수들이 함께 상호작용 함으로써 시너지를 발휘할 경우 긍정적인 반응성 수준이 높아 질 것이라고 하였다(Yeo, 2015). 또한 Luthans와 Youssef (2007) 에 따르면 긍정심리자본의 특징은 기질 특성으로 고정된 것이 아니라 상태적인 특징(state-like)을 지녀 개발 가능한 요인이므 로 연습 및 훈련을 통해 변화할 수 있다고 하였다.

이를 정리하면 긍정심리자본은 개인이 가진 가치를 긍정적 으로 평가하는 것으로, 긍정적 심리자본을 가진 개인들은 주
어진 환경에 적응하고, 목표를 달성하기 위한 능력이 개인 내 에 있다고 믿으며 이를 활용하여 성공적으로 나아갈 수 있을 것이다. 자기에 대한 긍정적 관점은 행복에 영향을 미친다는 M. J. Kim과 Ko (2106)의 연구결과처럼 긍정심리자본이 잘 형 성되어 있는 청소년들은 그렇지 않은 청소년들보다 자신의 가 치를 긍정적으로 평가하여 만족스러운 방향으로 자신을 발전 시키며, 행복한 성인으로 성장할 수 있을 것이다. 뿐만 아니라 개인의 노력 및 주변의 도움과 지지는 긍정심리자본을 향상시 킬 수 있는 기제로 작용할 수 있기 때문에 청소년을 대상으로 한 긍정심리자본에 영향을 미치는 변인들을 탐색하는 연구가 필요하다.

그러나 국내에서는 긍정심리자본의 연구가 시작단계에 있 으며, 대부분의 연구가 경영학 분야에서 조직관리와 인적관리 와 연관되어 있으며(Jung, 2013), 아동 및 청소년 연구에서는 진로분야와 관련된 연구가 주로 이루어질 뿐 어떠한 변수들이 긍정심리자본에 영향을 미치는가에 대한 연구는 찾아보기 어 려운 실정이다.

한편, 긍정심리자본을 구성하는 개별적인 하위요인에 대 한 연구는 어느 정도 이루어지고 있는데 이를 살펴보면 다음 과 같다. 자기효능감(self-efficacy)에 영향을 미치는 변인으로 성별(Jung, 2003; H. R. Lee, 2011), 학년(Shin, 2006), 기질(Pyun, 2012; Song, 2010), 부모의 양육태도(Noh \& Park, 2001; J. G. Park, 2002), 부모-자녀간 의사소통(Byun, 2014; T. J. Kim, 2006; Shin \& Jang, 2001), 사회적지지(Barrera, 1981; Harter, 1989; D. Y. Kim, Oh, \& Kim, 2012; Y. K. Lee, 2012), 정서지능(Kwak, 2004; J. H. Lee, Lee, \& Yoo, 2010; Moafian \& Ghanizadeh, 2009; Salovey \& Mayer, 1990) 등이 있는 것으로 보고되었다. 희 망(hope)에 영향을 미치는 변인에는 학업성취도(Curry, Snyder, Cook, Ruby, \& Rehm, 1997), 기질(Lim \& Moon, 2012), 양육 태도(H. R. Moon \& Lee, 2015), 애착(Jung, 2015; J. Y. Lee \& Choi, 2012; Shorney, Snyder, Yang, \& Lewin 2003), 사회적지지 (Jang, 2010), 긍정적 정서(S. Y. Park, 2013) 등이 있는 것으로 나 타났다. 복원력(resilience)에 영향을 미치는 변인으로는 성별 (S. H. Cho, 2012; Y. K. Kwon, 2010), 가정경제수준(H. J. Jang \& Moon, 2011; S. H. Lee, 2014), 부모의 학력(J. Y. Kim, 2008; S. H. Lee, 2014), 기질(Y. M. Cho, 2013; Jung, 2011; J. H. Kwon, 2006), 부모 양육태도(Garmezy, 1993; J. H. Lee, Choi, \& Han, 2012; Rutter, 1987), 부모-자녀간 의사소통(Lee, 2010; Yoon, 2012), 또래관계와 교사관계(Bagwell, Newcomn, \& Bukowski, 1998; Hur, 2004), 사회적지지(J. M. Kim, 2010; J. S. Park, 2009; Y. M. Park, 2010), 정서조절(Goo, 2012) 등이 보고되었다. 마지 
막으로 낙관성(optimism)에 영향을 미치는 변인으로는 기질 (Son, 2014), 양육태도(Hasan \& Power, 2002; Yang, 2015), 부모 애착(S. H. Cho, 2014; Lim, 2011; Peterson \& Bossio, 1991), 대 상관계수준(J. H. Lee, 2013; J. Y. Lee, Min, \& Kim, 2010), 사회 적지지(Myeong \& Kang 2011; Scheier \& Carver, 1992), 정서지 능(Y. O. Cho, 2008; Mayer \& Salovey, 1990) 등이 있는 것으로 나타났다. 이들 연구를 정리하면, 여러 변인 가운데 기질, 애 착, 양육태도, 사회적지지, 정서와 관련된 변인(긍정적 정서, 정서지능)들이 긍정심리자본의 하위요인에 공통적으로 영향 을 미치는 것으로 나타났다.

본 연구에서는 자기효능감, 희망, 복원력, 낙관성 등의 4 가 지 개념의 개별적인 효과보다 통합된 개념이 긍정심리자본 에 더 높은 영향을 미친다는 연구결과(J. Y. Kim \& Kim, 2011; Luthans et al., 2007)를 토대로 긍정심리자본의 하위변인들을 종합하여 통합적 개념으로 살펴보고자 한다. 더불어 긍정심 리자본의 선행변수에 관련된 국내·외 선행연구들을 찾아보 면, Khan (2013)의 연구에서는 개인적 배경(성별, 종교, 결혼 유무, 경제적수준), 멘토링, 부모·또래·형제자매의 교육적 지 지가 대학생의 긍정심리자본에 영향을 미친다고 나타났고, $\mathrm{Li}$ 등(2014)의 연구에서는 사회적지지가 대학생의 긍정심리자본 에 영향을 미친다고 나타났다. J. Y. Lee (2015)의 연구에서 개 인요인(성별, 성적, 정신건강), 가족요인(부모의 지원), 학교요 인(교사관계, 친구관계), 지역사회 요인(지역사회 지원, 지역 사회 상호작용)이 청소년의 긍정심리자본에 영향을 미친다고 나타났으며, Yeo (2015)의 연구에서는 사회적지지와 정서조절 이 호텔조직구성원의 긍정심리자본에 영향을 미친다고 나타 났다.

이상에서 살펴본 바와 같이 사회인구학적 배경, 기질, 사회 적지지, 정서조절능력이 중학생의 긍정심리자본과 긍정심리 자본의 하위요인에 영향을 미치는 주요한 변인이라는 것을 예 측할 수 있다. 그러나 선행연구들에서는 사회인구학적 변인 이나 사회적지지, 정서조절 중 한 두 가지 변인과 긍정심리자 본간의 관계를 주로 분석하였을 뿐 이러한 변인들을 포괄적으 로 선정하여 청소년의 긍정심리자본에 대한 상대적 영향력을 살펴본 연구는 찾아보기 힘들다. 또한 기질과 긍정심리자본의 하위요인인 자기효능감, 낙관성, 복원력, 희망과 관련된 선행 연구들은 있으나 기질과 긍정심리자본과의 관계를 통합적으 로 살펴본 연구가 없어 기질이 긍정심리자본에 어떠한 영향을 미치는지를 연구하는 것 또한 의미가 있을 것이라 사료된다. 또한, 청소년기 중에서도 중학교 2학년 학생들은 ‘중 2 병’이라 는 신조어를 낳을 정도로 사춘기적 특성을 강하게 나타내는
시기로 볼 수 있기 때문에 중학교 2학년 남녀 청소년을 대상으 로 긍정심리자본에 영향을 미치는 변인들을 연구하는 것은 매 우 의미있는 일이라 보겠다.

따라서 본 연구에서는 중학교 2학년 남녀학생을 대상으로 긍정심리자본에 영향을 미치는 변인들을 탐색하기 위해 선행 연구들의 결과를 기초로 사회인구학적 변인, 유전적 경향성에 해당되는 기질, 환경적 요인에 해당되는 사회적지지, 정서지 능의 하위요인에 해당되는 정서조절능력을 선정하고, 이들 변 인의 상대적 영향력을 분석해봄으로써 중학생의 긍정심리자 본을 향상시킬 수 있는 구체적 방안을 제안하기 위한 기초자 료를 마련하고자 한다. 이를 위해 본 연구에서 설정한 연구문 제는 다음과 같다.

\section{연구문제 1}

긍정심리자본에 대한 사회인구학적 변인, 기질, 사회적지지, 정서조절능력의 상대적 영향력은 어떠한가?

\section{연구문제 2}

긍정심리자본의 하위요인에 대한 사회인구학적 변인, 기질, 사회적지지, 정서조절능력의 상대적 영향력은 어떠한가?

\section{연구방법}

\section{연구대상}

본 연구는 광주광역시에 소재한 4 개 중학교 2학년 재학생을 대상으로 실시하였다. 연구대상을 중학교 2학년으로 선정한 이유는 아동기에서 성인기로 이행하는 과도기이며 사춘기 적 특성을 가장 잘 보이는 시기로서, 심리·사회적 적응이 중요 한 시기이기 때문이다. 연구대상자의 일반적 특성은 Table 1과 같다. 조사대상자의 성별을 보면, 남학생이 $47.3 \%$, 여학생이 $52.7 \%$ 로 여학생의 비율이 더 높게 나타났다. 가정 경제 수준 은 상위권이 $31.7 \%$, 중위권이 $63.4 \%$, 하위권이 $4.6 \%$ 로 자신 의 가정이 중위권에 속한다고 응답한 비율이 가장 높았다. 학 업 성적은 상위권이 $41.8 \%$, 중위권이 $27.5 \%$, 하위권이 $30.2 \%$ 로 자신의 성적이 상위권에 속한다고 응답한 비율이 가장 높 았다. 부의 교육수준은 고졸이하가 $25.7 \%$, 대학교 졸업이 $58.9 \%$, 대학원 이상이 $9.1 \%$ 로 나타났고, 모의 교육수준은 고 졸 이하가 $32.7 \%$, 대학교 졸업이 $46.3 \%$, 대학원 이상이 $5.5 \%$ 로 나타났다. 
Table 1

General Characteristics of Subjects

\begin{tabular}{|c|c|c|c|}
\hline Variable & $N(\%)$ & Variables & $N(\%)$ \\
\hline Gender & & ucation of father & \\
\hline Male & $318(47.3)$ & Under high school & $173(25.7)$ \\
\hline Female & $354(52.7)$ & University & $396(58.9)$ \\
\hline Economic condition & & Graduate school & $1 \quad(9.1)$ \\
\hline Low & $31 \quad(4.6)$ & Nothing response & $42 \quad(6.3)$ \\
\hline Average & $426(63.4)$ & & \\
\hline High & $213(31.7)$ & & \\
\hline Nothing response & $2(0.3)$ & & \\
\hline Academic achievement & & lucation of mother & \\
\hline Low & $203(30.2)$ & Under high school & $220(32.7)$ \\
\hline Average & $185(27.5)$ & University & $374(46.3)$ \\
\hline High & $281(41.8)$ & Graduate school & $37 \quad(5.5)$ \\
\hline Nothing response & $3(0.4)$ & Nothing response & $41 \quad(6.1)$ \\
\hline
\end{tabular}

Note. $N=672$.

\section{연구도구}

본 연구에서 사용된 도구는 청소년의 기질 척도, 사회적지지 척도, 정서조절능력 척도 및 긍정심리자본 척도이다.

\section{청소년 기질}

Cloninger, Pryzybeck, Svrakic와 Wetzel (1994)의 Temperament and Character Inventory (TCI)를 바탕으로 제작한 것으로 국 내에서 Oh와 Min (2004)이 독일형 JTCI 12-18을 표준화한 기 질 및 성격검사-청소년용(Junior Temperament and Character Inventory [JTCI])을 사용하였다. 기질 및 성격검사는 자극추 구, 위험회피, 사회적민감성, 인내력의 4가지 기질 차원과 자 율성, 연대감, 자기초월의 3가지 성격차원으로 구성되어 있으 나 본 연구에서는 4 가지 기질 차원만을 사용하였다. 자극추 구(novelty seeking)는 새로운 자극, 보상단 등에 반응하는 유전 적 경향성을 의미하고, 위험회피(harm avoidance)는 위험하거 나 혐오스러운 자극을 회피하게 하는 유전적 경향성을 의미하 며, 사회적민감성(reward dependence)은 사회적인 보상 신호에 반응하는 유전적 경향성을 의미하고, 인내력(Persistence)은 한 번 보상된 행동이 지속적 강화 없이도 일정 시간 동안 지속되 도록 하는 경향성을 의미한다. 기질 척도는 총 44 문항으로 구 성되어 있으며, 청소년 피검자가 각 문항에 동의하는 정도를 4 점 Likert 척도로 평정하며, 그렇지 않다(0점)에서 그렇다(3점)
으로 구성되었다. 각 하위척도의 신뢰도 계수(Cronbach's $\alpha$ )는 자극추구 .71 , 위험회피 .84, 사회적민감성 .63, 인내력 .63으로 나타났다.

$$
\text { 사회적지지 }
$$

청소년의 사회적지지는 Han과 Yoo (1996)가 개발한 척도를 사 용하였다. 이 척도는 Dubow와 Ullman (1989)이 아동을 대상 으로 조사해 개발한 the Social Support Appraisal Scale (SSAS)와 Scale of Available Behavior (SAB), 청소년의 대인 간 지지 평가 를 위해 Cohen과 Hoberman (1983)이 제작한 the Interpersonal Support Evaluation List (ISEL), 그리고 Lempers, Clark-Lempers 와 Simons (1989)의 Parenting Questionnaire (PQ)를 번안한 것 과 Sung (1993), Yoon (1993), M. S. Kim (1995) 등의 척도를 참 고로 하여 개발한 것이다. 사회적지지 척도는 친구지지, 가족 지지, 교사지지 각 8 문항씩 총 24 문항으로 구성되었으며, 각 문항에 대한 응답방식은 5점 척도로 전혀 그렇지 않다(1점) 부터 매우 그렇다(5점)로 응답하게 되어 있다. 부정적인 문항 은 역채점을 하였으며 점수가 높을수록 사회적 지지를 높게 지각한다는 것을 의미한다. 전체 사회적지지의 신뢰도 계수 (Cronbach's $\alpha$ )는 .93이며, 친구지지 .92, 가족지지 .93, 교사지 지 .90으로 나타났다. 


$$
\text { 정서조절능력 }
$$

청소년의 정서조절능력은 Salovey (1997)의 정서지능모형에 입각하여 Y. L. Moon (1999)이 개발한 청소년용 정서지능검사 의 다섯 가지 하위요인인 정서인식표현, 감정이입, 사고촉진, 정서활용, 정서조절 중 Jang (2010)이 사용한 정서조절척도를 사용하였다. 정서조절척도는 자기정서조절능력과 타인정서 조절능력으로 구성되어있으며, 자기정서조절은 자신의 정서 를 효과적으로 사용하는 능력을 의미하고, 타인정서조절은 타 인의 정서를 효과적으로 사용하는 능력을 의미한다. 자기정 서조절능력 8 문항, 타인정서조절능력 7 문항으로 총 15 문항이 고, 문항의 형식은 전혀 그렇지 않다(1점)에서 매우 그렇다(5 점)까지 5점 Likert척도로 구성되었으며, 점수가 높을수록 정 서조절능력이 높음을 의미한다. 전체 정서조절능력의 신뢰도 계수(Cronbach's $\alpha$ )는 .88이며, 자기정서조절능력 .82, 타인정 서조절능력 .82로 나타났다.

\section{긍정심리자본}

중학생의 긍정심리자본을 측정하기 위하여 Luthans 등(2007) 이 개발한 Psychological Capital Questionnaire (PCQ)를 청소 년 대상으로 Jung (2013)이 번안 및 수정한 척도를 아동학 전 공 교수 1 인과 아동학 박사 2 인의 안면타당도를 통하여 우리 나라 중학생 상황에 맞게 추가 수정하여 사용하였다. 이는 응 답자의 심리상태를 측정하기 위해 개발된 Parker (1998)의 자 기효능감척도, Snyder 등(1996)의 희망척도, Wagnild와 Young (1993)의 탄력성척도, Scheier와 Carver (1985)의 낙관성척도를 재구성한 것으로 자기효능감, 희망, 복원력, 낙관성 각 6 문항 씩 총 24문항으로 구성되었다. 전혀 그렇지 않다(1점)에서 매 우 그렇다(5점)까지 5점 Likert척도로 구성되었고, 부정적인 문항은 역채점 하여 점수가 높을수록 긍정심리자본이 높음을 의미하여, 전체 긍정심리자본의 신뢰도 계수(Cronbach's $\alpha$ )는 .92 이며, 자기효능감 .86 , 희망 .84 , 복원력 .74, 낙관성 .67로 나 타났다.

\section{사회인구학적 변인}

선행연구(Khan, 2013; J. Y. Lee, 2015)를 바탕으로 청소년의 긍 정심리자본에 영향을 미칠 것으로 예측되는 개인요인 및 가정 환경요인들을 사회인구학적 변인으로 설정하였다.

- 성별: 남자는 '0', 여자는 ' 1 '의 값으로 더미코딩 하였다.
- 학업성적: 주관적으로 인지한 학업성적을 하위권(1), 중위권 (2), 상위권(3)으로 구분하여 측정하였다.

- 가정경제수준: 주관적으로 인지한 가정경제수준을 하위권 (1), 중위권(2), 상위권(3)으로 구분하여 측정하였다.

- 부의 교육수준: 부의 교육수준을 고졸이하(1), 대학교 졸업 (2), 대학원 이상(3)으로 구분하여 측정하였다.

- 모의 교육수준: 모의 교육수준을 고졸이하(1), 대학교 졸업 (2), 대학원 이상(3)으로 구분하여 측정하였다.

\section{연구절차 및 자료분석}

본 조사에 앞서 검사지의 내용을 점검하고 소요시간을 알아 보기 위해 중학교 2학년 20명을 대상으로 예비조사를 실시하 였고, 예비조사 결과를 참고로 하여 검사의 이해와 질문의 답 변에 어려움이 있는 설문문항들을 수정하여 설문지 조사법으 로 본조사를 실시하였다. 남녀공학 중학교 4곳을 임의표집한 후, 중학교 2학년 남녀학생에게 총 750 부의 질문지를 배부하 였고, 그 중 727 부가 회수 되었으나 불성실하거나 기입항목이 누락된 자료를 제거하고 총 672 부의 자료를 분석에 사용하였 다. 질문지는 연구자가 해당 중학교를 방문하여 담임교사에게 연구의 취지와 작성요령을 설명하였고, 담임교사의 지도하에 학생이 직접 작성한 후 회수하였다.

본 연구에서 수집된 자료의 분석을 위하여 SPSS 18.0 (IBM Co., Armonk, NY) 통계 프로그램을 사용하여 빈도분석, 기술 통계분석, Pearson의 적률상관관계분석, 위계적 회귀분석을 실 시하였다

\section{연구결과}

\section{주요변인들의 기술 통계치}

주요 변인들의 기술 통계치는 Table 2 와 같다. 기질에 대해 살 펴보면, 자극추구 기질 평균은 1.41 로 중간점수(1.5점)보다 약 간 낮은 것으로 보이고, 위험회피 기질 평균은 1.65 , 사회적 민 감성 평균은 1.81 , 인내력 기질 평균은 1.73 으로 중간점수보 다 약간 높은 것으로 나타났다. 사회적지지 전체 평균은 3.32 로서 중간점수(3점)보다 높은 것으로 나타났으며, 하위변수 인 친구지지 평균은 3.75 , 가족지지 평균은 3.90 , 교사지지 평 균은 3.34로 나타나 중간점수보다 약간 높은 것으로 나타났 다. 정서조절능력 전체 평균은 3.75 로 나타나 중간점수(3점)보 
Table 2

Technical Statistics Major Variable

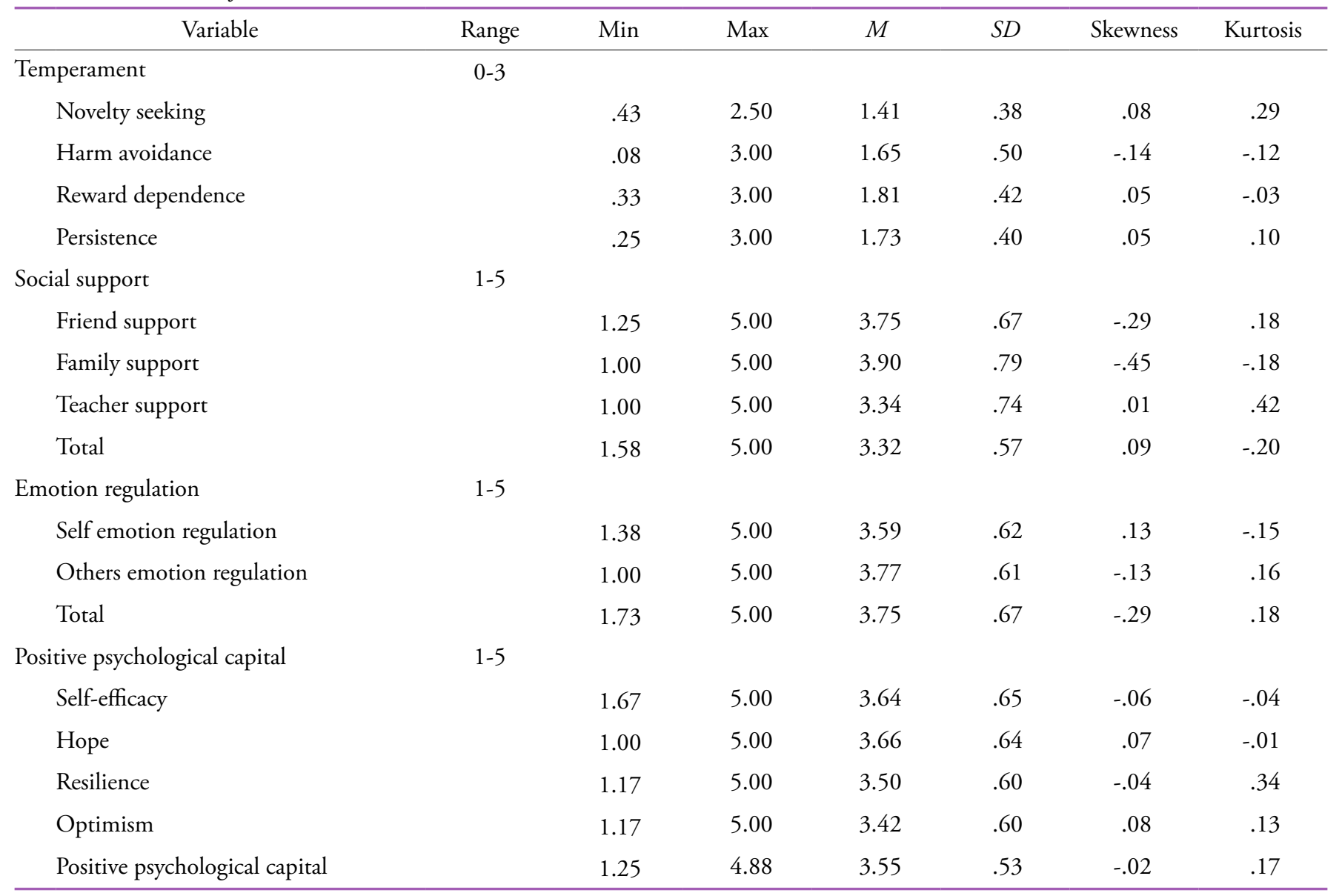

Note. $N=672$.

다 약간 높은 것으로 나타났으며, 하위변수인 자기정서조절능 력 평균은 3.59, 타인정서조절능력 평균은 3.77로 나타나 중간 점수보다 약간 높은 것으로 나타났다. 긍정심리자본 평균은 3.55 로 나타나 중간점수(3점)보다 약간 높은 것으로 나타났으 며, 하위변수인 자기효능감 평균은 3.64 , 희망 평균은 3.66 , 복 원력 평균은 3.50 , 낙관성 평균은 3.42 로 나타나 중간점수보다 약간 높은 것으로 나타났다.

왜도와 첨도 등을 살펴본 결과, 본 연구의 왜도는 절대값 .01-.45로 나타났고, 첨도는 절대값 .01-.42로 나타나 정규분 포의 기준값인 왜도(skewness) \pm 2 이하, 첨도(kurtosis) \pm 4 이하의 기준을 모두 충족함에 따라 이들 변인들은 정규분포를 이루고 있다고 할 수 있다(Bae, 2007).

\section{긍정심리자본과 관련 변인 간의 상관관계 분석}

주요변인들이 긍정심리자본과 어떠한 관련성을 맺고 있는지
알아보기 위해 상관관계분석을 실시하였다. 사회인구학적 변 인, 기질, 사회적지지, 정서조절능력, 긍정심리자본 사이의 Pearson 적률 상관분석 결과는 Table 3과 같다.

상관관계 분석 결과, 긍정심리자본은 사회인구학적 변인 중 성별 $(r=-.10, p<.01)$ 과는 부적상관을 보였으며, 부 교육 수준 $(r=.10, p<.05)$, 모 교육수준 $(r=.16, p<.001)$, 가정경제 수준 $(r=.20, p<.001)$, 학업성적 $(r=.34, p<.001)$ 과는 정적 상 관을 보였다. 긍정심리자본은 기질 하위요인 중 자극추구기 질 $(r=-.16, p<.001)$ 과 위험회피기질 $(r=-.29, p<.001)$ 과는 부 적 상관을 보였으며, 사회적민감성기질 $(r=.35, \mathrm{p}<.001)$ 과 인 내력기질 $(r=.52, p<.001)$ 과는 정적 상관을 보였다. 긍정심리 자본은 사회적지지 하위요인인 친구지지 $(r=.61, p<.001)$, 가 족지지 $(r=.61, p<.001)$, 교사지지 $(r=.40, \mathrm{p}<.001)$ 와 정적 상 관관계를 보였으며, 긍정심리자본은 정서조절능력 하위요인 인 자기정서조절능력 $(r=.68, p<.001)$, 타인정서조절능력 $(r=$ $.62, p<.001)$ 과 정적 상관을 보였다. 
Table 3

Correlation Analysis

$(N=672)$

\begin{tabular}{|c|c|c|c|c|c|c|c|c|c|c|c|c|c|c|c|c|c|c|c|}
\hline & 1 & 2 & 3 & 4 & 5 & 6 & 7 & 8 & 9 & 10 & 11 & 12 & 13 & 14 & 15 & 16 & 17 & 18 & 19 \\
\hline 1 & - & & & & & & & & & & & & & & & & & & \\
\hline 2 & -.06 & - & & & & & & & & & & & & & & & & & \\
\hline 4 & -.07 & $.19^{* * *}$ & $.21^{* * * *}$ & - & & & & & & & & & & & & & & & \\
\hline 5 & -.05 & $.17^{* * *}$ & $.16^{* * *}$ & $.16^{* * * *}$ & - & & & & & & & & & & & & & & \\
\hline 7 & $.14^{* * *}$ & -.04 & -.07 & $-.12^{* *}$ & -.07 & $.16^{* * *}$ & - & & & & & & & & & & & & \\
\hline 8 & $.31^{* * *}$ & $.08^{*}$ & .01 & .06 & .05 & -.07 & $-.11^{* *}$ & - & & & & & & & & & & & \\
\hline 9 & .03 & .04 & $.08^{*}$ & $.08^{*}$ & $.25^{* * *}$ & $-.36^{* * *}$ & $-.23^{* * *}$ & $.37^{* * * *}$ & - & & & & & & & & & & \\
\hline 10 & .07 & .06 & .07 & $.22^{* * *}$ & $.24^{* * *}$ & -.07 & $-.25^{* * *}$ & $.43^{* * * *}$ & $.32^{* * *}$ & - & & & & & & & & & \\
\hline 13 & -.05 & .08 & $.12^{* *}$ & $.16^{* * *}$ & $.18^{* * *}$ & $-.12^{* *}$ & $-.12^{* *}$ & $.30^{* * * *}$ & $.40^{* * * *}$ & $.45^{* * *}$ & $.46^{* * *}$ & $.32^{* * *}$ & - & & & & & & \\
\hline 14 & .05 & .06 & $.10^{* *}$ & $.16^{* * * *}$ & $.21^{* * *}$ & $-.12^{* *}$ & .01 & $.38^{* * * *}$ & $.43^{* * *}$ & $.51^{* * *}$ & $.45^{* * *}$ & $.40^{* * *}$ & $.62^{* * * *}$ & - & & & & & \\
\hline 15 & $-.09^{*}$ & $.09^{*}$ & $.15^{* * *}$ & $.18^{* * *}$ & $.33^{* * *}$ & -.07 & $-.22^{* * *}$ & $.31^{* * * *}$ & $.43^{* * *}$ & $.54^{* * *}$ & $.54^{* * *}$ & $.35^{* * *}$ & $.50^{* * * *}$ & $.54^{* * *}$ & - & & & & \\
\hline 16 & $-.08^{*}$ & $.11^{\text {** }}$ & $.20^{* * * *}$ & $.19^{* * *}$ & $.31^{* * *}$ & $-.12^{* *}$ & $-.16^{* * *}$ & $.29^{* * * *}$ & $.44^{* * *}$ & $.54^{* * *}$ & $.54^{* * *}$ & $.35^{* * *}$ & $.57^{* * * *}$ & $.58^{* * *}$ & $.75^{* * *}$ & - & & & \\
\hline 17 & $-.12^{* *}$ & .08 & $.09^{*}$ & $.17^{* * *}$ & $.28^{* * *}$ & $-.17^{* * *}$ & $-.32^{* * *}$ & $.28^{* * *}$ & $.45^{* * *}$ & $.49^{* * *}$ & $.49^{* * *}$ & $.36^{* * *}$ & $.63^{* * * *}$ & $.49^{* * *}$ & $.64^{* * *}$ & $.65^{* * *}$ & - & & \\
\hline 18 & -.05 & .06 & $.10^{*}$ & $.11^{\text {** }}$ & $.23^{* * *}$ & $-.19^{* * *}$ & $-.27^{* * *}$ & $.31^{* * *}$ & $.43^{* * *}$ & $.48^{* * *}$ & $.48^{* * *}$ & $.29^{* * *}$ & $.58^{* * * *}$ & $.47^{* * *}$ & $.47^{* * *}$ & $.55^{* * *}$ & $.60^{* * *}$ & - & \\
\hline 19 & $-.10^{* *}$ & $.10^{*}$ & $.16^{* * *}$ & $.20^{* * *}$ & $.34^{* * *}$ & $-.16^{* * *}$ & $-.29^{* * *}$ & $.35^{* * * *}$ & $.52^{* * *}$ & $.61^{* * *}$ & $.61^{* * *}$ & $.40^{* * *}$ & $.68^{* * * *}$ & $.62^{* * *}$ & $.85^{* * *}$ & $.88^{* * *}$ & $.85^{* * *}$ & $.77^{* * * *}$ & - \\
\hline
\end{tabular}

Note. $N=672$.

1 = gender; 2 = education of father; 3 = education of mother; 4 = economic condition; 5 = academic achievement; $6=$ novelty seeking; 7 = harm avoidance; 8 = reward dependence; 9 = persistence; 10 = friend support; 11 = family support; 12 = teacher support; 13 = self emotion regulation; 14 = others emotion regulation; 15 = self efficacy; $16=$ hope; 17 = resilience; $18=$ optimism; $19=$ positive psychological capital. ${ }^{*} p<.05 .{ }^{* *} p<.01 .{ }^{* * *} p<.001$.

\section{중학생의 기질, 사회적지지 및 정서조절능력 이 긍정심리자본에 미치는 상대적 영향력}

회귀모형을 구성하기 위하여 상관관계 분석을 실시한 결과, 기질, 사회적지지, 정서조절능력 모두 긍정심리자본과 유의한 관계가 있음을 알 수 있었다. 이러한 결과를 토대로 긍정심리 자본에 미치는 관련 변인들의 상대적 영향력을 알아보기 위해 사회인구학적 변인, 기질, 사회적지지, 정서조절능력을 독립 변인으로 선정하여 위계적 중다회귀분석을 실시하였다.

독립변인들 간에 다중공선성(multicollinearity)의 존재여부 를 파악하기 위해 분산팽창계수(VIF)와 Pearson의 적률상관계 수, 공차한계를 산출하였고, 분산팽창계수를 살펴본 결과, 그 범위가 1.02-2.18로 10보다 현저하게 작았고, Pearson의 적률
상관분석결과 가장 높은 상관계수가 .68로 모두 .7보다 작은 것으로 나타나 다중공선성 문제는 나타나지 않았다. 또한 공 차한계 분석결과 그 범위가 .46-.98로 나타나 독립적임을 알 수 있었다.

위계적 회귀분석에서 독립변수의 투입은 사회인구학적 변 인, 기질, 사회적지지, 정서조절능력 순서로 하였다. 1 단계에 서는 기본적인 선행변수인 사회인구학적 배경을 투입하였고, 2단계에서는 유전적 경향성인 기질을 투입하였고, 친구지지, 교사지지, 가족지지와 같은 사회적 지지가 정서조절능력과 정서조절능력을 하위요인으로 하는 정서지능에 영향을 미친 다는 선행연구(Asher \& Parker, 1989; Cassidy, Parke, Butdovsky, \& Braungart, 1992; Denham, 1993; Gottman \& Mettetal, 1986; Grossman \& Rhodes, 2002; S. J. Lee, 2006; Oh, 2006)를 바탕으 
로 사회적지지가 정서조절능력의 선행변수로 작용할 것이라 가정하여 3 단계에서는 사회적지지를 투입하고, 4단계에서 정 서조절능력을 투입하였다.

전체 긍정심리자본에 대한 관련변인의 영향력은 Table 4와 같다. 모형 1 에서 긍정심리자본에 연구대상자의 사회인구학 적 변인이 미치는 영향력을 분석한 결과 모형은 통계적으로 유의하였고 $(F=18.54, p<.001)$, 전체 긍정심리자본을 약 $13 \%$ 를 설명하였다. 사회인구학적 변인들 가운데 학업성적 $(\beta=$ $.28, p<.001)$, 가정경제수준 $(\beta=.13, p<.01)$ 이 통계적으로 유 의했고, 나머지 변인은 통계적으로 유의하지 않았다.

모형 2 에서 모형 1 에 중학생의 기질 변인을 추가하여 전체 긍정심리자본에 대한 영향력을 분석한 결과 모형은 통계적으 로 유의하였고 $(F=45.00, p<.001)$, 전체 긍정심리자본을 약 $40 \%$ 설명하였으며, 모형 1 에 비해 설명력이 $27 \%$ 증가하였다. 사회인구학적 변인과 기질 변인 가운데 인내력기질 $(\beta=.35, p$ $<.001)$, 사회적민감성기질 $(\beta=.25, p<.001)$, 학업성적 $(\beta=.19$, $p<.001)$, 성별 $(\beta=-.15, p<.001)$, 위험회피기질 $(\beta=-.15, p<$ $.001)$, 가정경제수준 $(\beta=.07, p<.05)$ 이 통계적으로 유의했고, 나머지 변인들은 통계적으로 유의하지 않았다.

모형 3에서 모형 2에 사회적지지 변인을 추가하여 전체 긍 정심리자본에 대한 영향력을 분석한 결과 모형은 통계적으로 유의하였고 $(F=64.01, p<.001)$, 전체 긍정심리자본을 약 $56 \%$ 설명하였고, 모형 2 에 비해 설명력이 $16 \%$ 증가하였다. 사회 인구학적 변인과 기질, 사회적지지 변인 가운데 친구지지 $(\beta=$ $.34, p<.001)$, 인내력기질 $(\beta=.28, p<.001)$, 가족지지 $(\beta=.15$, $p<.001)$, 학업성적 $(\beta=.14, p<.001)$, 성별 $(\beta=-.10, p<.01)$, 교 사지지 $(\beta=.10, p<.01)$, 위험회피기질 $(\beta=-.08, p<.01)$ 이 통 계적으로 유의했고, 나머지 변인들은 통계적으로 유의하지 않 았다.

모형 4에서 모형 3에 정서조절능력 변인을 추가하여 전체 긍정심리자본에 대한 영향력을 분석한 결과, 모형은 통계적 으로 유의하였고 $(F=86.76, p<.001)$, 전체 긍정심리자본을 약

Table 4

A Hierarchical Regression Analysis of Positive Psychological Capital

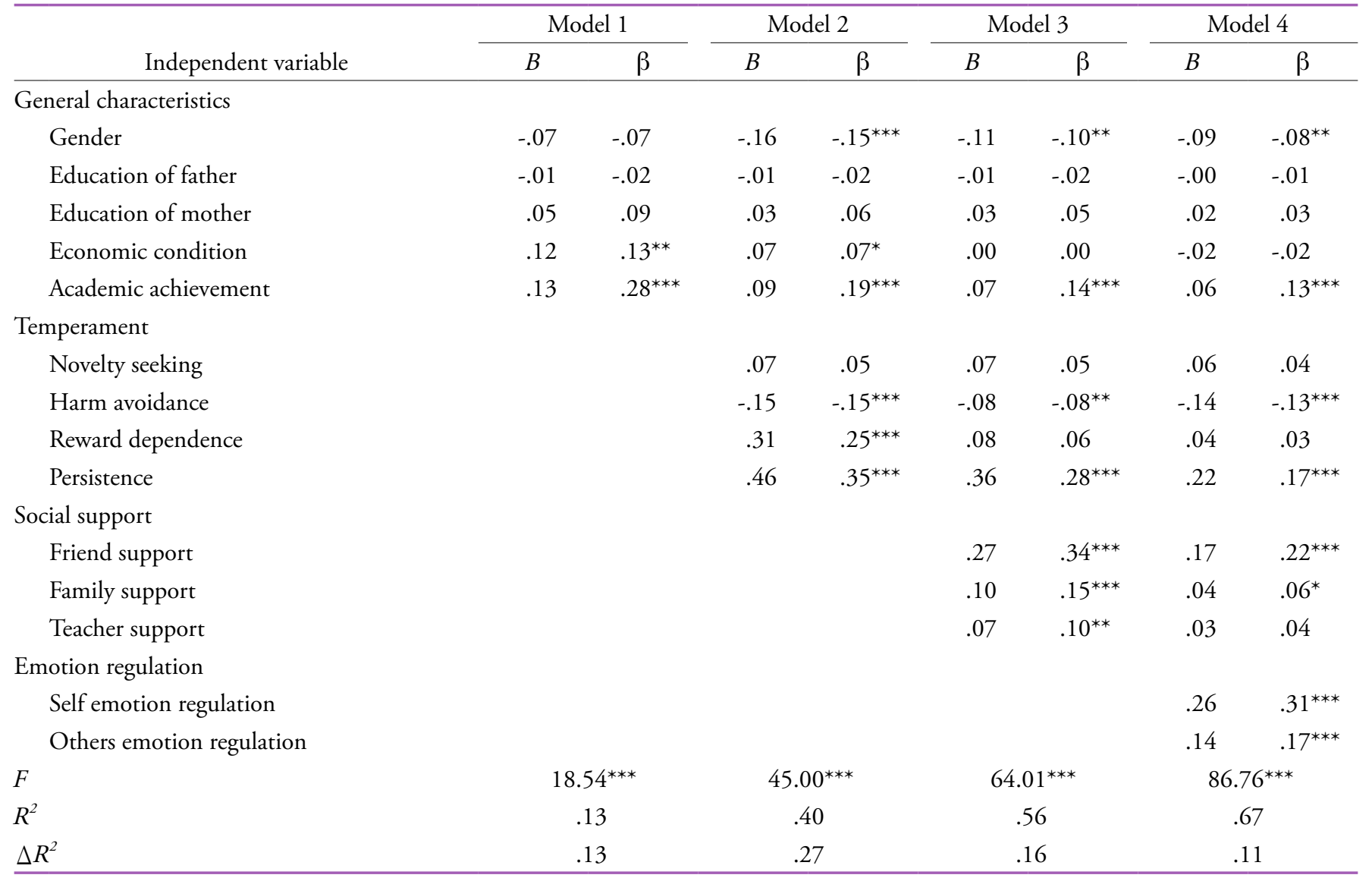

${ }^{*} p<.05 .{ }^{* *} p<.01 .{ }^{* * *} p<.001$. 
$67 \%$ 설명하였고, 모형 3 에 비해 설명력이 $11 \%$ 증가하였다. 사회인구학적변인과, 기질, 사회적지지, 정서조절능력 변인 가운데 자기정서조절능력 $(\beta=.31, p<.001)$, 친구지지 $(\beta=.22$, $p<.001)$, 인내력기질 $(\beta=.17, p<.001)$, 타인정서조절능력 $(\beta$ $=.17, p<.001)$, 학업성적 $(\beta=.13, p<.001)$, 위험회피기질 $(\beta$ $=-.13, p<.001)$, 성별 $(\beta=-.08, p<.01)$, 가족지지 $(\beta=.06, p<$ $.05)$ 가 통계적으로 유의했고, 나머지 변인은 통계적으로 유의 하지 않았다.

이들 결과를 종합하면, 긍정심리자본을 가장 잘 설명하는 변인군은 기질 변인군, 사회적지지 변인군, 사회인구학적 변 인군, 정서조절능력 변인군으로 나타났다. 또한, 전체 긍정심 리자본에 대한 개별 변인의 영향력을 살펴보면, 자기정서조절 능력, 친구지지, 인내력기질, 타인정서조절능력, 학업성적, 위 험회피기질, 성별, 가족지지 순으로 나타났다. 이는 자기정서 조절능력이 높을수록, 친구지지를 높게 지각할수록, 인내력기 질이 높을수록, 타인정서조절능력이 높을수록, 학업성적이 높 을수록, 위험회피기질이 낮을수록, 여학생보다는 남학생이, 가족지지를 높게 지각할수록 긍정심리자본이 높음을 알 수 있 다. 이는 여학생보다 남학생이, 성적이 좋을수록, 가족관계의 질이 좋을수록, 또래관계의 질이 좋을수록 긍정심리자본의 수 준이 높다는 G. S. Lee (2015)의 연구결과와 일치하며, 여성보 다 남성이, 친구와 가족의 격려를 받을수록 긍정심리강점이 높다는 Khan (2013)의 연구결과와 정서조절과 사회적지지가 긍정심리자본에 정적 영향을 미친다는 Yeo (2015)의 연구결과 를 지지한다.

또한, 모형이 추가됨에도 불구하고 성별, 학업성적, 위험회 피기질, 인내력기질, 친구지지가 계속적으로 유의한 영향을 미치는 것으로 드러나 이들 변인이 긍정심리자본에 중요한 영 향을 미친다는 것을 보여준다. 정서조절능력 역시 하위변인 모두가 긍정심리자본에 영향을 미치는 것을 보아 긍정심리자 본 향상에 있어 중요하다고 할 수 있겠다.

\section{중학생의 기질, 사회적지지 및 정서조절능력 이 긍정심리자본의 하위요인에 미치는 상대적 영향력}

\section{자기효능감에 대한 중학생의 기질, 사회적지지, 정서조절능력의 상대적 영향력}

자기효능감에 대한 관련변인의 영향력은 Table 5 와 같다. 모형 1 에서 자기효능감에 연구대상자의 사회인구학적 변인이 미치
는 영향력을 분석한 결과 모형은 통계적으로 유의하였고 $(F=$ $16.72, p<.001)$, 자기효능감을 약 $12 \%$ 설명하였다. 사회인구 학적 변인들 가운데 학업성적 $(\beta=.27, p<.001)$, 가정경제수준 $(\beta=.14, p<.01)$ 이 통계적으로 유의했고, 나머지 변인은 통계 적으로 유의하지 않았다.

모형 2 에서 모형 1 에 중학생의 기질 변인을 추가하여 자기 효능감에 대한 설명력을 분석한 결과 모형은 통계적으로 유의 하였고 $(F=30.77, p<.001)$, 자기효능감을 약 $31 \%$ 설명하였 으며, 모형 1에 비해 설명력이 $19 \%$ 증가하였다. 사회인구학적 변인과 기질 변인 가운데 인내력기질 $(\beta=.30, p<.001)$, 사회적 민감성 $(\beta=.24, p<.001)$, 학업성적 $(\beta=.21, p<.001)$, 성별 $(\beta=$ $-.15, p<.001)$, 자극추구기질 $(\beta=.13, p<.01)$, 위험회피 기질 $(\beta$ $=-.10, p<.01)$, 가정경제수준 $(\beta=.09, p<.05)$ 이 통계적으로 유의했고, 나머지 변인들은 통계적으로 유의하지 않았다.

모형 3에서 모형 2에 사회적지지 변인을 추가하여 자기효 능감에 대한 설명력을 분석한 결과 모형은 통계적으로 유의하 였고 $(F=38.85, p<.001)$, 자기효능감을 약 $44 \%$ 설명하였으며, 모형 2 에 비해 설명력이 $13 \%$ 증가하였다. 사회인구학적 변인 과 기질, 사회적지지 변인 가운데 친구지지 $(\beta=.32, p<.001)$, 인내력기질 $(\beta=.24, p<.001)$, 학업성적 $(\beta=.17, p<.001)$, 자 극추구기질 $(\beta=.13, p<.001)$, 교사지지 $(\beta=.11, p<.01)$, 성별 $(\beta=-.11, p<.01)$, 가족지지 $(\beta=.09, p<.05)$ 가 통계적으로 유 의했고, 나머지 변인들은 통계적으로 유의하지 않았다.

모형 4에서 모형 3에 정서조절능력 변인을 추가하여 자기 효능감에 대한 설명력을 분석한 결과, 모형은 통계적으로 유 의하였고 $(F=38.96, p<.001)$, 자기효능감을 약 $48 \%$ 설명하 였으며, 모형 3에 비해 설명력이 $4 \%$ 증가하였다. 사회인구학 적 변인과 기질, 사회적지지, 정서조절능력 변인 가운데 친구 지지 $(\beta=.24, p<.001)$, 타인정서조절능력 $(\beta=.20, p<.001)$, 인내력기질 $(\beta=.17, p<.001)$, 학업성적 $(\beta=.15, p<.001)$, 자 극추구기질 $(\beta=.12, p<.001)$, 자기정서조절능력 $(\beta=.10, p<$ $.01)$, 성별 $(\beta=-.10, p<.01)$, 위험회피기질 $(\beta=-.08, p<.05)$ 이 통계적으로 유의했고, 나머지 변인들은 통계적으로 유의하지 않았다.

이들 결과를 종합하면, 긍정심리자본의 하위요인인 자기효 능감을 가장 잘 설명하는 변인군은 기질 변인군, 사회적지지 변인군, 사회인구학적 변인군, 정서조절능력 변인군으로 나타 났다. 또한 자기효능감에 대한 개별 변인의 영향력을 살펴보 면, 자기효능감에 대한 개별 변인의 영향력은 친구지지, 타인 정서조절능력, 인내력기질, 학업성적, 자극추구기질, 자기정 서조절능력, 성별, 위험회피기질 순으로 나타났다. 이는 친구 
Table 5

A Hierarchical Regression Analysis of Self-Eficacy

\begin{tabular}{|c|c|c|c|c|c|c|c|c|}
\hline \multirow[b]{2}{*}{ Independent variable } & \multicolumn{2}{|c|}{ Model 1} & \multicolumn{2}{|c|}{ Model 2} & \multicolumn{2}{|c|}{ Model 3} & \multicolumn{2}{|c|}{ Model 4} \\
\hline & $B$ & $\beta$ & $B$ & $\beta$ & $B$ & $\beta$ & $B$ & $\beta$ \\
\hline \multicolumn{9}{|l|}{ General characteristics } \\
\hline Gender & -.09 & -.07 & -.19 & $-.15^{* * *}$ & -.14 & $-.11^{* *}$ & -.13 & $-.10^{* *}$ \\
\hline Education of father & -.02 & -.03 & -.02 & -.03 & -.02 & -.02 & -.01 & -.01 \\
\hline Education of mother & .05 & .08 & .03 & .05 & .03 & .04 & .02 & .03 \\
\hline Economic condition & .15 & $.14^{* *}$ & .09 & $.09^{*}$ & .02 & .02 & .01 & .01 \\
\hline Academic achievement & .16 & $.27^{* * *}$ & .12 & $.21^{* * *}$ & .10 & $.17^{* * *}$ & .09 & $.15^{* * *}$ \\
\hline \multicolumn{9}{|l|}{ Temperament } \\
\hline Novelty seeking & & & .22 & $.13^{* *}$ & .21 & $.13^{* * *}$ & .20 & $.12^{* * *}$ \\
\hline Harm avoidance & & & -.12 & $-.10^{* *}$ & -.05 & -.04 & -.11 & $-.08^{*}$ \\
\hline Reward dependence & & & .36 & $.24^{* * *}$ & .11 & .07 & .08 & .05 \\
\hline Persistence & & & .48 & $.30^{* * *}$ & .38 & $.24^{* * *}$ & .27 & $.17^{* * *}$ \\
\hline \multicolumn{9}{|l|}{ Social support } \\
\hline Friend support & & & & & .31 & $.32^{* * *}$ & .23 & $.24^{* * *}$ \\
\hline Family support & & & & & .07 & $.09^{*}$ & .03 & .04 \\
\hline Teacher support & & & & & .09 & $.11^{* *}$ & .06 & .06 \\
\hline \multicolumn{9}{|l|}{ Emotion regulation } \\
\hline Self emotion regulation & & & & & & & .11 & $.10^{* *}$ \\
\hline Others emotion regulation & & & & & & & .21 & $.20^{* * *}$ \\
\hline$F$ & \multicolumn{2}{|c|}{$16.72^{* * *}$} & \multicolumn{2}{|c|}{$30.77^{* * *}$} & \multicolumn{2}{|c|}{$38.85^{* * *}$} & \multicolumn{2}{|c|}{$38.96^{* * *}$} \\
\hline$R^{2}$ & \multicolumn{2}{|c|}{.12} & \multicolumn{2}{|c|}{.31} & \multicolumn{2}{|c|}{.44} & \multicolumn{2}{|c|}{.48} \\
\hline$\Delta R^{2}$ & \multicolumn{2}{|c|}{.12} & \multicolumn{2}{|c|}{.19} & \multicolumn{2}{|c|}{.13} & \multicolumn{2}{|c|}{.04} \\
\hline
\end{tabular}

${ }^{*} p<.05 .{ }^{* *} p<.01 .{ }^{* * *} p<.001$.

지지를 높게 지각할수록, 타인정서조절능력이 높을수록, 인내 력기질이 높을수록, 학업성적이 높을수록, 자극추구기질이 높 을수록, 자기정서조절능력이 높을수록, 여학생보다는 남학생 이, 위험회피기질이 낮을수록 자기효능감이 높음을 의미한다.

\section{희망에 대한 중학생의 기질, 사회적지지, 정서 조절능력의 상대적 영향력}

희망에 대한 관련변인의 영향력은 Table 6 과 같다. 모형 1 에 서 희망에 연구대상자의 사회인구학적 변인이 미치는 영향력 을 분석한 결과 모형은 통계적으로 유의하였고 $(F=16.19, p<$ $.001)$, 희망을 약 $12 \%$ 설명하였다. 사회인구학적 변인들 가운 데 학업성적 $(\beta=.24, p<.001)$, 모의 교육수준 $(\beta=.15, p<.01)$, 가정경제수준 $(\beta=.12, p<.01)$ 이 통계적으로 유의했고, 나머 지 변인들은 통계적으로 유의하지 않았다.

모형 2 에서 모형 1 의 독립변인에 중학생의 기질 변인을 추
가하여 희망에 대한 설명력을 분석한 결과, 모형은 통계적으 로 유의하였고 $(F=27.55, p<.001)$, 희망을 약 $29 \%$ 설명하였 으며, 모형 1 에 비해 설명력이 $17 \%$ 증가하였다. 사회인구학 적 변인과 기질 변인 가운데 인내력기질 $(\beta=.31, p<.001)$, 사 회적민감성기질 $(\beta=.22, p<.001)$, 학업성적 $(\beta=.17, p<.001)$, 성별 $(\beta=-.14, p<.001)$, 모의 교육수준 $(\beta=.12, p<.01)$, 가정 경제수준 $(\beta=.08, p<.05)$ 이 통계적으로 유의했고, 나머지 변 인들은 통계적으로 유의하지 않았다.

모형 3에서 모형 2 의에 사회적지지 변인을 추가하여 희망 에 대한 설명력을 분석한 결과, 모형은 통계적으로 유의하였 고 $(F=38.51, p<.001)$, 희망을 약 $43 \%$ 설명하였으며, 모형 2 에 비해 설명력이 $14 \%$ 증가하였다. 사회인구학적 변인과 기 질, 사회적지지 변인 가운데 친구지지 $(\beta=.31, p<.001)$, 인내 력기질 $(\beta=.23, p<.001)$, 가족지지 $(\beta=.17, p<.001)$, 학업성 적 $(\beta=.12, p<.001)$, 모의 교육수준 $(\beta=.11, p<.01)$, 성별 $(\beta=$ $-.09, p<.01)$, 교사지지 $(\beta=.08, p<.05)$ 가 통계적으로 유의했 
Table 6

A Hierarchical Regression Analysis of Hope

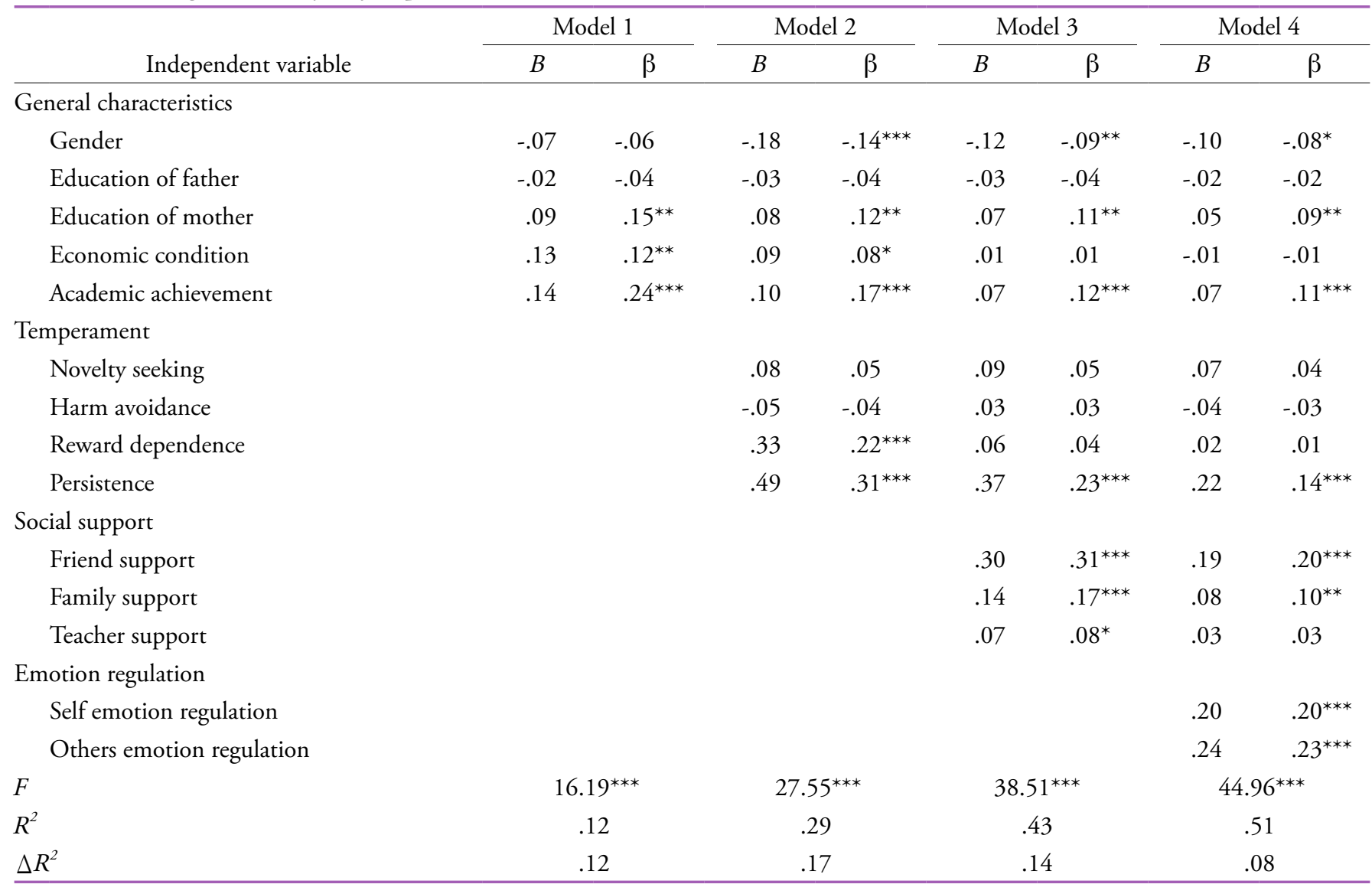

${ }^{*} p<.05 .{ }^{* *} p<.01 .{ }^{* * *} p<.001$.

고, 나머지 변인들은 통계적으로 유의하지 않았다.

모형 4에서 모형 3에 정서조절능력 변인을 추가하여 희망 에 대한 설명력을 분석한 결과 모형은 통계적으로 유의하였 고 $(F=44.96, p<.001)$, 희망을 약 $51 \%$ 설명하였으며 모형 3 에 비해 설명력이 $8 \%$ 증가하였다. 사회인구학적 변인과 기질, 사회적지지, 정서조절능력 변인 가운데 타인정서조절능력 $(\beta$ $=.23, p<.001)$, 자기정서조절능력 $(\beta=.20, p<.001)$, 친구지 지 $(\beta=.20, p<.001)$, 인내력기질 $(\beta=.14, p<.001)$, 학업성적 $(\beta=.11, p<.001)$, 가족지지 $(\beta=.10, p<.01)$, 모의 교육수준 $(\beta$ $=.09, p<.01)$, 성별 $(\beta=-.08, p<.01)$ 이 통계적으로 유의했고, 나머지 변인들은 통계적으로 유의하지 않았다.

이들 결과를 종합하면, 긍정심리자본의 하위요인인 희망을 가장 잘 설명하는 변인군은 기질 변인군, 사회적지지 변인군, 사회인구학적 변인군, 정서조절능력 변인군으로 나타났다. 또 한 희망에 대한 개별 변인의 영향력은 타인정서조절능력, 자 기정서조절능력, 친구지지, 인내력기질, 학업성적, 가족지지,
모의 교육수준, 성별 순으로 나타났다. 이는 타인정서조절능 력과 자기정서조절능력이 높을수록, 친구지지와 가족지지를 높게 지각할수록, 인내력기질이 높을수록, 학업성적이 높을수 록, 모의 교육수준이 높을수록, 여학생보다는 남학생이 희망 이 높음을 의미한다.

\section{복원력에 대한 중학생의 기질, 사회적지지, 정 서조절능력의 상대적 영향력}

복원력에 대한 관련변인의 영향력은 Table 7과 같다. 모형 1 에 서 복원력에 연구대상자의 사회인구학적 변인이 미치는 영향 력을 분석한 결과 모형은 통계적으로 유의하였고 $(F=12.54$, $p<.001)$, 복원력을 약 $9 \%$ 설명하였다. 사회인구학적 변인들 가운데 학업성적 $(\beta=.23, p<.001)$, 가정경제수준 $(\beta=.11, p$ $<.01)$, 성별 $(\beta=-.09, p<.05)$ 이 통계적으로 유의했고, 나머지 변인들은 통계적으로 유의하지 않았다. 
Table 7

A Hierarchical Regression Analysis of Resilience

\begin{tabular}{|c|c|c|c|c|c|c|c|c|}
\hline \multirow[b]{2}{*}{ Independent variable } & \multicolumn{2}{|c|}{ Model 1} & \multicolumn{2}{|c|}{ Model 2} & \multicolumn{2}{|c|}{ Model 3} & \multicolumn{2}{|c|}{ Model 4} \\
\hline & $B$ & $\beta$ & $B$ & $\beta$ & $B$ & $\beta$ & $B$ & $\beta$ \\
\hline \multicolumn{9}{|l|}{ General characteristics } \\
\hline Gender & -.11 & $-.09^{*}$ & -.17 & $-.14^{* * *}$ & -.13 & $-.10^{* *}$ & -.09 & $-.08^{*}$ \\
\hline Education of father & .00 & .00 & .00 & .00 & .00 & .00 & 01 & .01 \\
\hline Education of mother & .02 & .03 & .00 & .01 & -.00 & -.01 & -.01 & -.02 \\
\hline Economic condition & .12 & $.11^{* *}$ & .06 & .06 & .00 & .00 & -.01 & -.01 \\
\hline Academic achievement & .13 & $.23^{* * *}$ & .08 & $.15^{* * *}$ & .06 & $.12^{* * *}$ & .06 & $.11^{* * *}$ \\
\hline \multicolumn{9}{|l|}{ Temperament } \\
\hline Novelty seeking & & & .04 & .03 & .05 & .03 & .03 & .02 \\
\hline Harm avoidance & & & -.24 & $-.20^{* * *}$ & -.18 & $-.15^{* * *}$ & -.22 & $-.19^{* * *}$ \\
\hline Reward dependence & & & .26 & $.18^{* * *}$ & .06 & .04 & .02 & .01 \\
\hline Persistence & & & .46 & $.30^{* * *}$ & .36 & $.24^{* * *}$ & .21 & $.14^{* * *}$ \\
\hline \multicolumn{9}{|l|}{ Social support } \\
\hline Friend support & & & & & .21 & $.24^{* * *}$ & .11 & $.12^{* * *}$ \\
\hline Family support & & & & & .10 & $.14^{* * *}$ & .03 & .04 \\
\hline Teacher support & & & & & .07 & $.09^{*}$ & .04 & .05 \\
\hline \multicolumn{9}{|l|}{ Emotion regulation } \\
\hline Self emotion regulation & & & & & & & .39 & $.40^{* * *}$ \\
\hline Others emotion regulation & & & & & & & .07 & .07 \\
\hline$F$ & \multicolumn{2}{|c|}{$12.54^{* * *}$} & \multicolumn{2}{|c|}{$30.44^{* * *}$} & \multicolumn{2}{|c|}{$34.17^{* * *}$} & \multicolumn{2}{|c|}{$48.65^{* * *}$} \\
\hline$R^{2}$ & \multicolumn{2}{|c|}{.09} & \multicolumn{2}{|c|}{.31} & \multicolumn{2}{|c|}{.41} & \multicolumn{2}{|c|}{.53} \\
\hline$\Delta R^{2}$ & \multicolumn{2}{|c|}{.09} & \multicolumn{2}{|c|}{.22} & \multicolumn{2}{|c|}{.10} & \multicolumn{2}{|c|}{.12} \\
\hline
\end{tabular}

${ }^{*} p<.05 .{ }^{* *} p<.01 .{ }^{* * *} p<.001$.

모형 2 에서 모형 1 에 중학생의 기질 변인을 추가하여 복원 력에 대한 설명력을 분석한 결과 모형은 통계적으로 유의하였 고 $(F=30.44, p<.001)$, 복원력을 약 $31 \%$ 설명하였으며 모형 1 에 비해 설명력이 $22 \%$ 증가하였다. 사회인구학적 변인과 기 질 변인 가운데 인내력기질 $(\beta=.30, p<.001)$, 위험회피기질 $(\beta$ $=-.20, p<.001)$, 사회적민감성기질 $(\beta=.18, p<.001)$, 학업성 적 $(\beta=.15, p<.001)$, 성별 $(\beta=-.14, p<.001)$ 이 통계적으로 유 의했고, 나머지 변인들은 통계적으로 유의하지 않았다.

모형 3에서 모형 2에 사회적지지 변인을 추가하여 복원력 에 대한 설명력을 분석한 결과 모형은 통계적으로 유의하였고 $(F=34.17, p<.001)$, 복원력을 약 $41 \%$ 설명하였으며 모형 2에 비해 설명력이 $10 \%$ 증가하였다. 사회인구학적 변인과 기질, 사회적지지 변인 가운데 인내력기질 $(\beta=.24, p<.001)$, 친구지 지 $(\beta=.24, p<.001)$, 위험회피기질 $(\beta=-.15, p<.001)$, 가족지 지 $(\beta=.14, p<.001)$, 학업성적 $(\beta=.12, p<.001)$, 성별 $(\beta=-.10$, $p<.01)$, 교사지지 $(\beta=.09, p<.05)$ 가 통계적으로 유의했고, 나
머지 변인들은 통계적으로 유의하지 않았다.

모형 4에서 모형 3에 정서조절능력 변인을 추가하여 복원 력에 대한 설명력을 분석한 결과 모형은 통계적으로 유의하였 고 $(F=48.65, p<.001)$, 복원력을 약 $53 \%$ 설명하였으며, 모형 3 에 비해 설명력이 $12 \%$ 증가하였다. 사회인구학적 변인과 기 질, 사회적지지, 정서조절능력 변인 가운데 자기정서조절능력 $(\beta=.40, p<.001)$, 위험회피기질 $(\beta=-.19, p<.001)$, 인내력기 질 $(\beta=.14, p<.001)$, 친구지지 $(\beta=.12, p<.001)$, 학업성적 $(\beta=$ $.11, p<.001)$, 성별 $(\beta=-.08, p<.05)$ 이 통계적으로 유의했고, 나머지 변인들은 통계적으로 유의하지 않았다.

이들 결과를 종합하면, 긍정심리자본의 하위요인인 복원력 을 가장 잘 설명하는 변인군은 기질 변인군, 정서조절능력 변 인군, 사회적지지 변인군, 사회인구학적 변인군으로 나타닜 다. 또한 복원력에 대한 개별 변인의 영향력은 자기정서조절 능력, 위험회피기질, 인내력기질, 친구지지, 학업성적, 성별 순 으로 나타났다. 이는 자기정서조절능력이 높을수록, 위험회피 
Table 8

A Hierarchical Regression Analysis of Optimism

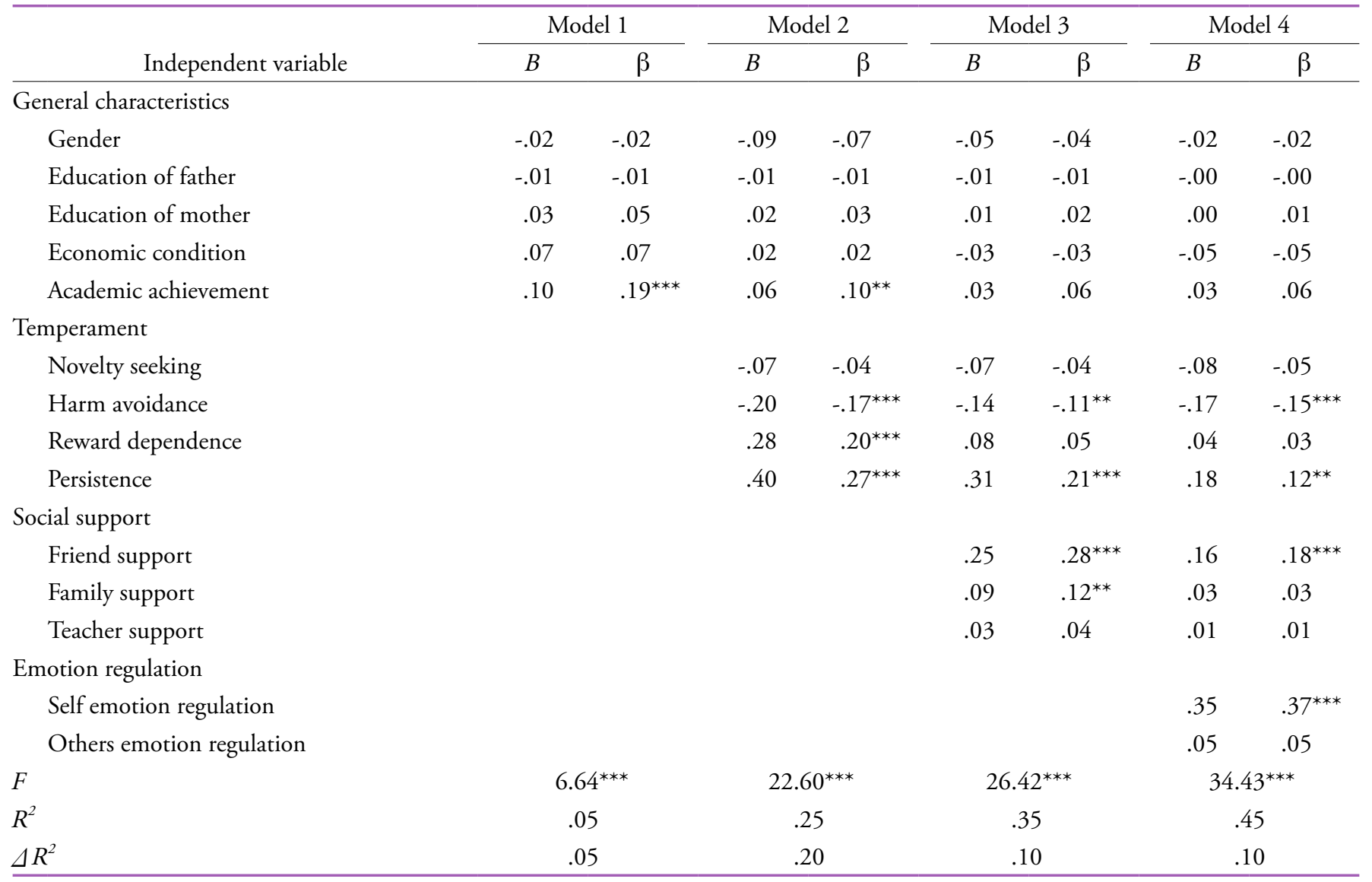

${ }^{*} p<.05 .{ }^{* *} p<.01 .{ }^{* * *} p<.001$.

기질이 낮을수록, 인내력기질이 높을수록, 친구지지를 높게 지각할수록, 학업성적이 높을수록, 남학생이 여학생보다 복원 력이 높은 것을 의미한다.

낙관성에 대한 중학생의 기질, 사회적지지, 정 서조절능력의 상대적 영향력

낙관성에 대한 관련변인의 영향력은 Table 8 과 같다. 모형 1에 서 낙관성에 연구대상자의 사회인구학적 변인이 미치는 영향 력을 분석한 결과 모형은 통계적으로 유의하였고 $(F=6.64, p$ $<.001)$, 낙관성을 약 $5 \%$ 설명하였다. 사회인구학적 변인들 가 운데 학업성적 $(\beta=.19, p<.001)$ 만이 통계적으로 유의했고, 나 머지 변인들은 통계적으로 유의하지 않았다.

모형 2 에서 모형 1 에 중학생의 기질 변인을 추가하여 낙관 성에 대한 설명력을 분석한 결과 모형은 통계적으로 유의하였 고 $(F=22.60, p<.001)$, 낙관성을 약 $25 \%$ 의 설명하였으며, 모
형 1 에 비해 설명력이 $20 \%$ 증가하였다. 사회인구학적 변인과 기질 변인 가운데 인내력기질 $(\beta=.27, p<.001)$, 사회적민감성 기질 $(\beta=.20, p<.001)$, 위험회피기질 $(\beta=-.17, p<.001)$, 학업 성적 $(\beta=.10, p<.01)$ 이 통계적으로 유의했고, 나머지 변인들 은 통계적으로 유의하지 않았다.

모형 3에서 모형 2에 사회적지지 변인을 추가하여 낙관성 에 대한 설명력을 분석한 결과 모형은 통계적으로 유의하였고 $(F=26.42, p<.001)$, 낙관성을 약 $35 \%$ 설명하였으며 모형 2에 비해 설명력이 $10 \%$ 증가하였다. 사회인구학적 변인과 기질, 사회적지지 변인 가운데 친구지지 $(\beta=.28, p<.001)$, 인내력기 질 $(\beta=.21, p<.001)$, 가족지지 $(\beta=.12, p<.01)$, 위험회피기질 $(\beta$ $=-.11, p<.01)$ 이 통계적으로 유의했고, 나머지 변인들은 통계 적으로 유의하지 않았다.

모형 4에서 모형 3에 정서조절능력 변인을 추가하여 낙관 성에 대한 설명력을 분석한 결과 모형은 통계적으로 유의하였 고 $(F=34.43, p<.001)$, 낙관성을 약 $45 \%$ 설명하였으며 모형 3 
에 비해 설명력이 $10 \%$ 증가하였다. 사회인구학적 변인과 기 질, 사회적지지, 정서조절능력 변인 가운데 자기정서조절능력 $(\beta=.37, p<.001)$, 친구지지 $(\beta=.18, p<.001)$, 위험회피기질 $(\beta$ $=-.15, p<.001)$, 인내력기질 $(\beta=.12, p<.01)$ 이 통계적으로 유 의했고, 나머지 변인들은 통계적으로 유의하지 않았다.

이들 결과를 종합하면, 긍정심리자본의 하위요인인 낙관성 을 가장 잘 설명하는 변인군은 기질 변인군, 사회적지지 변인 군, 정서조절능력 변인군, 사회인구학적 변인군으로 나타났 다. 또한 낙관성에 대한 개별 변인의 영향력은 자기정서조절 능력, 친구지지, 위험회피기질, 인내력기질 순으로 나타났다. 이는 자기정서조절능력이 높을수록, 친구지지를 높게 지각할 수록, 위험회피기질이 낮을수록, 인내력기질이 높을수록 낙관 성이 높은 것을 의미한다.

\section{논의 및 결론}

본 연구의 결과를 요약하고 논의하면 다음과 같다. 첫째, 연구 대상자의 사회인구학적 변인, 중학생의 기질, 사회적지지, 정 서조절능력을 독립변인으로 하여 긍정심리자본에 대한 상대 적 영향력을 알아보기 위해 위계적 회귀분석을 실시한 결과 전체 설명력은 $67 \%$ 였다. 긍정심리자본을 가장 잘 설명하는 변인군은 기질 변인군, 사회적지지 변인군, 사회인구학적 변 인군, 정서조절능력 변인군으로 나타났고, 전체 긍정심리자본 에 대한 독립변인들의 상대적 영향력은 자기정서조절능력, 친 구지지, 인내력기질, 타인정서조절능력, 학업성적, 위험회피 기질, 성별, 가족지지 순으로 나타났다. 사회인구학적 변인 중 에서는 학업성적과 성별이 유의한 영향력을 갖는 것으로 나타 났는데, 이는 학업성적이 높을수록, 남학생이 여학생보다 긍 정심리자본이 높다는 것을 의미한다. 남학생이 여학생보다 긍 정심리자본이 높게 나타난 이유는 여학생들이 남학생에 비해 민감하게 자신의 가치를 평가하려는 경향 때문으로 추측되며, 이는 여성보다 남성이 긍정심리자본을 높게 지각한다는 선행 연구 결과(Khan, 2013; G. S. Lee, 2015)를 지지한다.

또한, 학업성적이 높을수록 긍정심리자본을 높게 지각하 는 것으로 나타났는데 이는 학업성적이 우수할수록 긍정심리 자본이 높다는 선행연구들(Jun, 2014; G. S. Lee, 2015)의 결과 를 지지한다. 기질 하위요인 중에서는 인내력기질과 위험회피 기질이 긍정심리자본에 영향을 미치는 것으로 드러났는데 이 는 근면, 끈기, 성취에 대한 야망이 높을수록, 불확실성에 대 한 두려움이나 불안감이 낮을수록 긍정심리자본이 높음을 의
미한다. 즉, 낮선 자극에 대한 두려움으로 행동을 억제하기 보 다는 성취에 대한 욕구를 가지고 성실하게 목표를 지향해 나 아가는 청소년들이 긍정심리자본을 높게 지각한다고 할 수 있 다. 사회적지지 하위요인 중에서는 친구지지와 가족지지가 긍 정심리자본에 영향을 미치는 것으로 드러나 친구지지와 가족 지지를 높게 지각할수록 긍정심리자본이 높다는 것을 보여주 며, 이는 사회적지지가 긍정심리자본에 영향을 미친다는 $\mathrm{Li}$ 등 (2014)의 선행연구 결과를 지지한다. 즉, 친구나 가족과 같은 주변사람들에게 인정받고 지지받는다고 느끼는 청소년들이 긍정심리자본을 높게 지각한다고 할 수 있다. 정서조절능력 하위요인 모두 중학생의 긍정심리자본에 중요한 영향을 미치 는 것으로 나타났는데 이는 긍정심리자본을 설명하는데 있어 정서조절능력 역시 매우 중요한 변인임을 보여주는 결과이며, 정서조절능력이 긍정심리자본에 영향을 미친다는 Yeo (2015) 의 연구결과를 지지한다. 즉, 자신의 긍정적인 정서를 잘 유지 하고 타인의 감정을 조절하고 통제하기 위해 행동방식을 적절 하게 조절하는 청소년들이 긍정심리자본을 높게 지각한다고 할 수 있다.

둘째, 사회인구학적 변인, 중학생의 기질, 사회적지지, 정서 조절능력을 독립변인으로 하여 긍정심리자본의 하위요인인 자기효능감에 대한 상대적 영향력을 알아보기 위해 위계적 회 귀분석을 실시한 결과 이들 변인은 자기효능감을 $48 \%$ 설명하 였다. 자기효능감을 가장 잘 설명하는 변인군은 기질 변인군, 사회적지지 변인군, 사회인구학적 변인군, 정서조절능력 변인 군으로 나타났고, 자기효능감에 대한 독립변인들의 상대적 영 향력은 친구지지가 가장 크고, 타인정서조절능력, 인내력기 질, 학업성적, 자극추구기질, 자기정서조절능력, 성별, 위험회 피기질 순으로 나타났다. 사회인구학적 변인 중에서는 학업성 적과 성별이 유의한 영향력을 갖는 것으로 나타났는데 이는 학업성적이 높을수록, 여학생보다는 남학생이 자기효능감이 높음을 의미한다. 학업성적이 높을수록 자기효능감이 높다는 결과는 G. S. Lee (2015)의 연구결과와 일치한다.

기질 변인에서는 인내력기질, 자극추구기질, 위험회피기 질 순으로 영향을 미치는 것으로 나타났다. 인내력기질이 자 기효능감에 영향을 미친다는 결과는 기질 하위요인 중 지속 성이 자기효능감과 정적인 관계가 있다는 선행연구와 유사한 결과이다(Lee, 2010; Multon, Brown, \& Lent, 1991). 긍정심리 자본과 긍정심리자본의 하위요인 중 자기효능감에서만 자극 추구기질이 정적 영향을 미치는 것으로 나타났는데, 이는 행 동 활성화 시스템(Behavior Activation System [BAS])와 자기효 능감이 정적 상관이 있다는 연구결과(Song, 2010)를 바탕으로, 
두뇌의 행동 활성화 시스템인 BAS와 관련되어 자극을 탐색하 게 하고 새로운 활동을 추구하게 하는 자극추구 기질이 자기 효능감에 영향을 미친다고 볼 수 있다. 위험회피기질이 자기 효능감에 영향을 미친다는 결과는 위험회피기질이 높을수록 낮은 자기효능감을 가지고 있다는 Pyun (2012)의 연구결과와 일치한다. 사회적지지 하위요인 중 친구지지가 자기효능감에 가장 중요한 영향을 미치는 변인으로 나타났는데 이는 사춘기 시기에 친구에게 지지받고 인정받는 것이 자신의 가치를 평가 하는데 아주 중요한 영향을 미친다는 것을 보여주며, 이는 또 래관계가 자기효능감에 정적 영향을 미친다는 선행연구(D. Y. $\mathrm{Kim}, \mathrm{Oh} \& \mathrm{Kim}, 2012$; G. S. Lee, 2015)의 연구결과와 일치한 다. 정서조절능력 하위요인 모두가 자기효능감에 영향을 미친 다는 것은 정서조절능력 변인 역시 자기효능감을 설명하는데 있어 중요한 변인이며, 이는 정서조절능력이 자기효능감에 영 향을 미친다는 선행연구(Yeo, 2015; You, 2013)를 지지하는 결 과이다.

셋째, 사회인구학적 변인, 중학생의 기질, 사회적지지, 정서 조절능력을 독립변인으로 하여 긍정심리자본의 하위요인인 희망에 대한 상대적 영향력을 알아보기 위해 위계적 회귀분 석을 실시한 결과 이들 변인은 희망을 $51 \%$ 설명하였다. 희망 을 가장 잘 설명하는 변인군은 기질 변인군, 사회적지지 변인 군, 사회인구학적 변인군, 정서조절능력 변인군으로 나타났으 며, 희망에 대한 독립변인들의 상대적 영향력은 타인정서조절 능력이 가장 크고, 자기정서조절능력, 친구지지, 인내력기질, 학업성적, 가족지지, 모의 교육수준, 성별 순으로 나타났다. 사 회인구학적 변인에서는 학업성적, 모의 교육수준, 성별 순으 로 희망에 영향을 미치는 것으로 나타났는데 이는 학업성적이 높을수록, 모의 교육수준이 높을수록, 여학생보다는 남학생이 희망을 높게 지각함을 의미한다. 모의 교육수준이 희망에 영 향을 주는 것으로 나타났는데 이는 어머니의 교육정도가 대졸 이상 집단이 중졸, 초졸 이하 집단보다 희망점수가 높은 것으 로 나타난 No (2004)의 연구를 지지하는 결과이다.

기질 변인에서는 인내력기질만이 희망에 영향을 미치는 것 으로 나타났는데 이는 근면이나 끈기, 성취에 대한 야망이 높 은 청소년이 개인의 목표를 달성하기 위해 포기하지 않고 나 아가는 경향성이 높음을 의미한다고 볼 수 있다. 사회적지지 변인에서는 친구지지, 가족지지 순으로 희망에 영향을 미치 는 것으로 나타났는데 이는 친구와 가족으로부터 인정과 지지 를 받는 청소년일수록 희망을 높게 갖는다는 것을 의미하며, 부모지지와 친구지지가 높을수록 희망이 높다는 선행연구 $(\mathrm{H}$. I. Cho, 2009; Jang, 2010) 결과와 일치한다. 정서조절능력 하위
요인 모두가 희망에 영향을 미치는 것으로 나타나 정서조절능 력 역시 희망을 설명하는데 있어 중요한 변인임을 알 수 있고, 이는 정서조절능력이 희망에 영향을 미친다는 선행연구(Yeo, 2015)와 일치한다.

넷째, 사회인구학적 변인, 중학생의 기질, 사회적지지, 정서 조절능력을 독립변인으로 하여 긍정심리자본의 하위요인인 복원력에 대한 상대적 영향력을 알아보기 위해 위계적 회귀분 석을 실시한 결과 이들 변인은 복원력을 $53 \%$ 설명하였다. 복 원력을 가장 잘 설명하는 변인군은 기질 변인군, 정서조절능 력 변인군, 사회적지지 변인군, 사회인구학적 변인군으로 나 타났고, 복원력에 대한 독립변인들의 상대적 영향력은 자기정 서조절능력이 가장 크고, 위험회피기질, 인내력기질, 친구지 지, 학업성적, 성별 순으로 나타났다. 사회인구학적 변인에서 는 학업성적, 성별 순으로 복원력에 영향을 미치는 것으로 나 타났는데, 이는 학업성적이 높을수록, 여학생보다는 남학생이 복원력이 높다는 것을 의미한다. 기질 변인에서는 위험회피기 질과 인내력기질 순으로 복원력에 영향을 주는 것으로 나타났 는데 이는 위험회피기질이 낮을수록, 인내력기질이 높을수록 복원력이 높음을 의미한다. 이는 한 가지 일에 오랜 시간 몰두 하는 성향인 지속성 기질이 자아탄력성과 정적 관련이 있고, 새로운 자극에 적응하는 것이 어려우며 익숙한 것만 고집하는 경직성 기질과는 부적 관련이 있다는 Jung (2011)의 연구결과 를 지지한다.

사회적지지 변인에서는 친구지지만이 복원력에 영향을 미 치는 것으로 나타났는데, 이는 친구지지가 아동의 자아탄력 성에 영향을 미친다는 선행연구(J. S. Park, 2009; Y. M. Park, 2010)의 연구결과를 지지하는 결과이다. 자기정서조절능력은 복원력에 가장 큰 영향을 미치는 변인으로 나타났는데 이는 자신의 긍정적인 기분 및 정서를 유지하는 청소년일수록 특정 한 결과를 성취할 수 있다는 개인의 능력에 대한 믿음이 높다 는 것을 의미하며, 긍정적 정서를 효과적으로 사용하는 것이 자아탄력성에 영향을 미친다는 Tugade와 Fredrickson (2004)의 연구결과와 일치한다.

다섯째, 사회인구학적 변인, 중학생의 기질, 사회적지지, 정 서조절능력을 독립변인으로 하여 긍정심리자본의 하위요인 인 낙관성에 대한 상대적 영향력을 알아보기 위해 위계적 회 귀분석을 실시한 결과 이들 변인은 낙관성을 $45 \%$ 설명하였 다. 낙관성을 가장 잘 설명하는 변인군은 기질 변인군, 사회적 지지 변인군, 정서조절능력 변인군, 사회인구학적 변인군으로 나타났고, 독립변인들의 낙관성에 대한 상대적 영향력은 자기 정서조절능력이 가장 크고, 친구지지, 위험회피기질, 인내력 
기질 순으로 나타났다. 사회인구학적 변인은 낙관성에 영향 을 미치지 않는 것으로 나타났는데 이는 낙관성은 성별, 출생 순위, 연령과 같은 사회인구학적 요소들에 의해 영향을 받기 보다는 기질과 노력, 정서적 차이 등 개인적 경향성에 의해 형 성된다는 Choi (2012)의 연구결과를 지지한다. 기질 변인에서 는 위험회피기질과 인내력기질이 낙관성에 영향을 미치는 것 으로 나타났는데 이는 활력이 넘치고 자신감이 있으며, 끈기 있게 성취를 지향하는 청소년일수록 실패했더라도 다시 재도 전하고, 미래를 낙관하는 것으로 사료된다. 사회적지지 변인 에서는 친구지지가 낙관성에 영향을 미치는 것으로 나타났 는데 이는 또래지지가 낙관성에 영향을 미친다는 선행연구 (Myeong, 2011; J. S. Park, 2009) 결과와 일치한다. 자기정서조 절능력이 낙관성에 가장 큰 영향을 미치는 변인으로 나타났는 데 이는 자신의 긍정적인 기분을 유지하려고 노력하는 청소년 일수록 긍정적인 사건을 내재적 요인과 연관시켜 파악한다는 것을 의미하며, 이는 자기정서조절이 낙관성에 유의한 영향을 미친다는 $\operatorname{Lim}(2011)$ 의 연구결과와 일치한다.

이상의 결과들을 바탕으로 결론을 도출하면 다음과 같다. 첫째, 사회인구학적 변인이 긍정심리자본에 영향을 미치는 것 으로 나타났는데, 학업성적과 성별은 긍정심리자본과 긍정심 리자본 하위요인 중 자기효능감, 희망, 복원력에 영향을 미치 는 것으로 나타났으며, 모의 교육수준은 희망에 영향을 미치 는 것으로 나타났다. 학업성적이 긍정심리자본에 영향을 미치 는 것으로 나타났는데 이는 학업성적을 통한 성취경험이 자신 감을 증진시켜 자신의 가치를 긍정적으로 평가하게 함을 의미 한다고 하겠다. 여학생보다는 남학생이 긍정심리자본 및 자 기효능감, 희망, 복원력을 높게 지각하는 것으로 나타나, 앞으 로 긍정심리자본 형성 및 향상에 있어서 성에 따른 차이를 구 체적으로 분석하는 연구가 이루어진다면 남.녀 중학생에 대한 실제적인 개입 방안을 마련하는데 도움이 될 것으로 사료된 다. 모의 교육수준이 희망에 영향을 미치는 것으로 나타 났는 데, 이는 모의 교육수준과 자녀의 목표지향의식과의 관련성을 보여주며 모의 학력이 높을수록 자녀의 목표설정 및 목표지향 행동에 긍정적 영향을 미친다는 것을 추측해 볼 수 있다. 즉, 사회인구학적 특성에 맞는 다양한 프로그램을 개발하여 개별 청소년들에게 적합한 긍정심리자본 향상 프로그램을 제공하 는 것이 필요하다고 하겠다.

둘째, 기질 변인은 긍정심리자본과 긍정심리자본 하위요 인을 가장 잘 설명해주는 변인군으로 나타났는데, 이는 긍정 심리자본에 있어 유전적 요인의 중요성을 보여준다. 특히 인 내력기질은 긍정심리자본과 긍정심리자본 하위요인 모두에
영향을 미치는 것으로 나타났다. 이는 인내력 성향이 높을수 록 야망을 가지고 지속적인 노력을 기울여 실제로 더 많은 것 을 성취하게 하고(B. B. Min, Oh, \& Lee, 2007), 이러한 성취 경 험을 통해 자신의 가치를 긍정적으로 평가하는 것으로 해석된 다. 위험회피기질은 긍정심리자본과 자기효능감, 복원력, 낙 관성에 영향을 미치는 것으로 나타났는데 이는 자신감이 있 고, 낙관적인 성향을 가진 청소년들이 자신의 가치에 대해 긍 정적으로 평가하는 것으로 해석된다. 자극추구기질은 자기효 능감에 영향을 미치는 것으로 나타났는데 이는 탐색적이고 호 기심이 많으며 열정적인 성향을 가진 청소년들이 자신의 가치 에 대해 긍정적으로 평가하는 것으로 해석된다. 기질이 중요 하다는 결과를 바탕으로 기질적 취약성이 있다고 판단되는 청 소년들의 긍정심리자본을 향상시킬 수 있도록 상담 및 개입이 필요하다고 하겠다. 또한 중학생 스스로 자신의 기질적 특성 을 이해하고 변화하는 노력을 할 수 있도록 기질에 대한 검사 및 교육의 활성화가 필요하다고 하겠다.

셋째, 사회적지지 변인 역시 긍정심리자본 및 긍정심리자 본의 하위요인에 영향을 미치는 것으로 나타났는데 이는 유 전적 요인 뿐 아니라 환경적인 요인 역시 긍정심리자본 형성 에 중요한 영향을 미친다는 것을 보여준다. 즉, 사회적 지지를 통해 사회적 관계에 대한 안정감을 느낄 때 청소년들이 개인 에 대한 긍정적인 가치 및 긍정적인 심리적 메커니즘을 활용 할 수 있다는 것을 의미한다. 이는 긍정심리자본을 향상시키 기 위해 사회적 지지를 높일 수 있는 환경조성에 대한 중요성 을 보여준다. 사회적지지 변인 중 친구지지가 긍정심리자본 과 긍정심리자본 하위요인 모두를 설명해주는 변인으로 나타 났는데 이는 사회적지지 중 또래들의 지지와 인정을 청소년 기들이 가장 중요하게 생각한다는 것을 보여주는 결과이다. 따라서 청소년들이 지지적이고 안정적인 또래관계를 형성할 수 있도록 집단 프로그램 및 또래관계 증진 프로그램을 제공 하는 것이 필요하다고 하겠다. 가족지지 역시 긍정심리자본 과 희망에 영향을 미치는 변인으로 나타났는데, 이는 가족구 성원에게 인정과 지지를 받는 청소년들이 자신의 가치에 대 해 긍정적으로 평가한다는 것을 의미한다. 따라서 부모 및 가 족원들의 인정과 지지의 중요성을 인식시키기 위한 부모교육 및 가족과의 긍정적인 상호작용 도모를 위한 가족상담을 제 공하는 것이 필요하다고 하겠다.

넷째, 정서조절능력 변인 역시 긍정심리자본과 긍정심리자 본 하위요인에 영향을 미치는 것으로 나타났다. 정서조절능력 변인 중 자기정서조절능력은 긍정심리자본 및 긍정심리자본 하위요인 모두에 영향을 미치는 것으로 나타났으며, 특히 긍 
정심리자본, 복원력, 낙관성을 가장 잘 설명하는 변인으로 나 타나 긍정적인 정서를 스스로 유지하려고 노력하는 청소년일 수록 긍정심리자본이 높다는 것을 의미한다. 타인정서조절능 력은 긍정심리자본과 자기효능감, 희망에 영향을 미치는 변인 으로 나타났으며 특히 희망을 가장 잘 설명하는 변인으로 나 타났다. 이는 타인의 감정을 조절하는 능력과 타인에게 보여 주는 자신에 대한 인상을 조절하는 능력이 뛰어난 청소년일수 록 목표달성에 대한 기대 및 목표 지향 능력이 높다는 것을 의 미한다. 따라서 청소년들이 자신과 타인의 정서를 효과적으로 조절할 수 있는 능력을 함양할 수 있도록 정서조절 프로그램 개발을 개발하고 제공하는 것이 필요하다고 하겠다.

다섯째, 전체 긍정심리자본과 긍정심리자본의 하위요인별 로 영향을 미치는 변인들이 다르게 나타났다. 전체 긍정심리 자본, 복원력, 낙관성에서는 자기정서조절이 가장 중요한 변 수로 나타났고, 자기효능감에서는 친구지지가, 희망에서는 타 인조절능력이 가장 중요한 변수로 나타났다. 이는 긍정심리자 본 향상에 있어 다양한 변인들과의 관계를 고려하여 보다 광 범위하고 체계적으로 접근해야 하며, 전체 긍정심리자본과 하 위요인을 고려한 다양한 프로그램 개발의 필요성을 보여준다 고 하겠다.

본 연구의 제한점과 후속 연구를 위한 제언을 하면 다음과 같다. 첫째, 본 연구의 대상을 광주 지역의 중학교 2 학년으로 제한하였으므로 후속연구에서는 표집지역을 다양화하고 확 대하여 연구대상의 대표성과 일반화 가능성을 높여야 할 것이 다. 둘째, 자기보고식 설문지 작성으로 연구가 진행되어 정확 한 심리상태나 심리적 가치를 파악하는데 한계가 있을 수 있 다고 판단된다. 향후 면접이나 관찰을 통한 질적 연구도 기대 해본다. 또한 심리적 요인측정 방법에 있어서 조건과 상황 등 다양한 접근법을 적용한 연구가 이루어지는 것이 필요하다. 셋째, 성별이 긍정심리자본에 영향을 미치는 것으로 나타나 남, 녀를 구분하여 긍정심리자본에 대해 연구하는 것도 의미 가 있을 것으로 본다. 넷째, 본 연구의 결과를 토대로 청소년의 긍정심리자본을 증진시킬 수 있는 상담이나 집단 프로그램에 대한 개발 및 효과성 연구가 이루어지는 것이 필요하다.

이러한 제한점에도 불구하고 본 연구는 중학생의 긍정심리 자본에 영향을 미치는 관련변인들의 영향력을 밝힘으로써, 긍 정심리자본을 향상시킬 수 있는 방안을 모색하여 청소년들의 심리적 역량을 키우고 긍정적인 성장을 돕도록 기초적 자료를 제공하는데 의의가 있다.

\section{Conflict of Interest}

No potential conflict of interest relevant to this article was reported.

\section{References}

Asher, S., \& Parker, J. (1989). Significance of peer relationship problems in childhood. In B. Schneider, G. Attili, J. Nadel $\&$ R. P. Weissberg (Eds.), Social competence in developmental perspective (pp. 5-23). Amsterdam' The Nethertands: Kluwer Academic.

Bae, B. R. (2007). Structural equation modeling with AMOS 7: Principles and practice. Seoul, Korea: Cheong Ram Press.

Bagwell, C. L., Newcomn, A. F., \& Bukowski, W. M. (1998). Preadolescent friendship and peer rejection as predictors of adult adjustment. Child Development, 69(1), 140-153.

Barrera, M. (1981). Social Support in the adjustment of preadolescent: Assessment Issues. In B. H. Gottlieb (Ed.). Social Networks and Social Support. Beverly Hills, CA:Sage.

Byun, H. H. (2014). A study on effects of communication patterns between parents and adolescents on self-efficacy and selfdirected learning of high school students (Unpublished master's thesis). Hanyang University, Seoul, Korea.

Cassidy, J., Parke, R. D., Butkovsky, L., \& Braungart, J. M. (1992). Family-peer connections: The roles of emotional expressiveness within the family and children's understanding of emotions. Child Development, 63, 603618.

Cho, H. I. (2009). The mediation effect of hope on the relationship between the social support and academic achievement. Journal of Elementary Education, 22(3), 65-87.

Cho, S. H. (2012). The influence of parent attachment on primary school children's adaptation to school life: Mediating effect of ego-resilience (Unpublished master's thesis). Chonnam National University, Gwangju, Korea.

Cho, S. H. (2014). The mediating effects of optimism in the relationship between parent attachment and psychological well-being in adolescent (Unpublished master's thesis). Sookmyung Women's University, Seoul, Korea.

Cho, Y. K. (2011). A study of airline cabin crew's positive psychological capital effect on job attitude and customer orientation (Unpublished master's thesis). Kyounggi University, Suwon, Korea.

Cho, Y. M. (2013). Effect of attention span and persistence temperament, affectionate rearing attitudes of mother and family support on behavior problem of child: Focused on the mediating effects of self-resilience (Unpublished doctoral 
dissertation). Chonnam National University, Gwangju, Korea.

Cho, Y. O. (2008). The relationship between optimism and emotion intelligence for middle school students. Journal of Evaluation on Counselling, 1(1), 53-71.

Choi, H. L. (2012). The Moderating effects of defense mechanism style on the relationship between optimism and well-being in Adolescents (Unpublished master's thesis). Seoul Women's University, Seoul, Korea.

Cloninger, C. R., Przybeck, T. R., Svrakic, D. M., \& Wetzel, R. D. (1994). The Temperament and Character Inventory (TCI): A guide to its development and use. St. Louis, MO: Center for Psychobiology of Personality.

Cohen, S., \& Hoberman, H. M. (1983). Positive events and social supports as buffers of life change stress. Journal of Applied Social Psychology, 13(2), 99-125.

Curry, L. A., Snyder, C. R., Cook, D. L., Ruby B. C., \& Rehm, M. (1997). Role of hope in academic and sport achievement. Journal of Personality and Social Psychology, 73(6), 12571267.

Denham, S. A. (1993). Maternal emotional responsiveness and toddlers' social-emotional competence. Journal of Child Psychology and Psychiatry, 34(5), 715-728.

Dubow, E. F., \& Ullman, D. G. (1989). Assessing social support in elementary school children: The survey of children's social support. Journal of Clinical Child Psychology, 18, 52-64.

Garmezy, N. (1993). Children in poverty: Resilience despite risk. Psychiatry: Interpersonal and Biological Processes, 56(1), 127136.

Goo, S. Y. (2012). The influence of positive affect on resilience: Mediated moderating effect of emotion regulation through social connectedness (Unpublished master's thesis). Catholic University of Korea, Seoul, Korea.

Gottman, J. M., \& Mettetal, G. (1986). Speculations about social and affective development: Friendship and acquaintanceship thought adolescence. In J. M. Gottman \& J. G. Parker (Eds.), Conversations of friends: Speculations on affective development. New York, NY: Cambridge University Press.

Grossman, J. B., \& Rhodes, J. E. (2002). The test of time: Predictors and effects of duration in youth mentoring relationships. American journal of Community Psychology, 30(2), 199-219.

Han, M. H., \& Yoo, A. J. (1996). The relation of stress and perceived social support to problem behavior. Korean Journal of Child Studies, 17(1), 173-188.

Harter, S. (1989). Development and dynamic changes in the nature of the self-concept: Implications for child psychotherapy. In S. R. Shrink (Ed), Cognitive development and child psychotherapy (pp. 119-160). New York, NY: Plenum Press.
Hasan, N., \& Power, T. G. (2002). Optimism and pessimism in children: A study of parenting correlates. International Journal of Behavioral Development, 26(2), 185-191.

Hur, J. Y. (2004). Study on the relationship among adolescents' resilience, peer relation and facilitative communication competence (Unpublished master's thesis). Seoul Women's University, Seoul, Korea.

Jang, H. J.(2010). Relationship between social support and level of hope in adolescents (Unpublished master's thesis). Korea University Seoul, Korea.

Jang, H. J., \& Moon, H. J. (2011). The effects of social capital of child's perceived parent-child relationship, ego-resilience and sociodemographic variables on children's happiness. Journal of Korean Child Care and Education, 7(3), 21-42.

Jang, S. H. (2010). The effect of adolescent's emotional regulation and parenting behavior on school adjustment (Unpublished master's thesis). Sungkyunkwan University, Seoul, Korea.

Jun, J. Y. (2014). Influences of the positive psychological capital perceived by adolescents on career barriers and career preparation behaviors (Unpublished master's thesis). Soon Chun Hyang University, Asan, Korea.

Jung, E. Y. (2013). The effect of psychological capital on career barriers and career maturity of high school girls (Unpublished master's thesis). Myongji University, Seoul, Korea.

Jung, G. W. (2015). The relationship between parent attachment, peer attachment and hope in adolescents (Unpublished master's thesis). Korea University, Seoul, Korea.

Jung, J. Y. (2011). Effects of temperament, family strength and social support on ego-resilience of adolescents (Unpublished master's thesis). Korea University, Seoul, Korea

Jung, Y. J. (2003). The relationship among emotional intelligence, selfefficacy and school-related adjustment (Unpublished master's thesis). Hong-ik University, Seoul, Korea.

Khan, A. (2013). Predictors of positive psychological strengths and subjective well-being among north Indian adolescents: Role of mentoring and educational encouragement. Social Indicators Research, 114(3), 1285-1293.

doi: $10.1007 / \mathrm{s} 11205-012-0202-\mathrm{x}$

Kim, D. Y., Oh, O. S., \& Kim, S. B. (2012). Mediating effect of self-efficacy between social support and career maturity among high school students. Korean Journal of Youth Studies, 19(5), 71-91.

Kim, J. M. (2010). Effects of psychological home environment and social support perceived by children of economical neglected class (the low-income families) on resilience (Unpublished master's thesis). Sungkyunkwan University, Seoul, Korea.

Kim, J. Y. (2008). Their relations among ego-resilience, subjective well-being, stress level and coping methods perceived by elementary students (Unpublished master's thesis). Yonsei University Seoul, Korea. 
Kim, J. Y., \& Kim, M. S. (2011). The effects of positive psychological capital on employee job satisfaction and affective commitment. Korean Business Education Review, 67, 117-148.

Kim, M. J., \& Ko, J. H. (2016). Family cohesion and happiness of Youth: Mediating effects of a positive attitude. Korean Journal Child Study, 37(1), 83-94. doi:10.5723/ kjcs.2016.37.1.83

Kim, M. S. (1995). The relation between social support and maladjustment of children (Unpublished doctoral dissertation). Sookmyung Women's University, Seoul, Korea.

Kim, T. J. (2006). Effects of parent-child communication pattern and peer relationship perceived by middle school students on their self-efficacy (Unpublished master's thesis). Kyungnam University, Changwon, Gyeongnam Korea.

Kwak, Y. J.(2004). Developing a model for designing emotional intelligence education programs (Unpublished Doctoral dissertation). Seoul National University, Seoul, Korea.

Kwon, J. H. (2006). Study on explanatory variables of ego-resilience of children (Unpublished master's thesis). Seoul Women's University, Seoul, Korea.

Kwon, Y. K. (2010). Parent nurturing attitude and self resilience of child following to employment configuration of major fosterer (Unpublished master's thesis). Daegu University, Daegu, Korea.

Lee, G. S. (2015). Study on the positive psychological capital of adolescent (Unpublished master's thesis). Dongguk University, Seoul, Korea.

Lee, H. R. (2011). The relationship of self-efficacy and goalorientation to career maturity of elementary students by gender (Unpublished master's thesis). Konkuk University, Seoul, Korea.

Lee, H. S. (2010). Relations among self-efficacy, environmental factors, personality, and academic achievement in medical students (Unpublished master's thesis). Wonkwang University, Iksan, Jeonbuk, Korea.

Lee, J. H. (2013). The mediating effects of optimism on the relationships between object relation level and peer relation for adolescents (Unpublished master's thesis). Sookmyung Women's University, Seoul, Korea.

Lee, J. H., Han, H. S., \& Choi, R. (2012). Mediated effect of positive emotion between parenting self-efficacy and parenting stress of mothers. Korean Journal of Children's Media, 11(2), 89-109.

Lee, J. H., Lee, H. W., \& Yoo, J. K. (2010). The Analysis of the effects between early childhood teachers' perceived emotional intelligence, their self-efficacy, and emotional labor in early childhood setting. Early Childhood Education \& Care, 5(2), 117-136.
Lee, J. M. (2010). Relationship among mother-child communication, ego-resiliency and school adaptation, as perceived by the adolescents (Unpublished master's thesis). Chung-Ang University, Seoul, Korea.

Lee, J. Y., \& Choi, H. C. (2012). Hope as a mediator between adult attachment and depression in university students. Korea Journal of Counselling, 13(2), 819-838.

Lee, J. Y., Min, S. H., \& Kim, M. J. (2010). The effect of teenagers' object relation level on optimism: With the mediation of soothing ability. Youth Facilities and Environment, 8(2), 1322.

Lee, K. S. (2015). Study on the positive psychological capital of adolescent (Unpublished master's thesis). Dongkuk University, Seoul, Korea.

Lee, K. Y., \& Song, J. S. (2010). The effect of psychological capital on empowerment and learning performance. Journal of Korea Safety Management \& Science, 12(4), 289-300.

Lee, M. H., \& Shin, H. J. (2015). The mediating effects of selfdetermination on the relationship between parental academic support and career maturity. The Korea Educational Review, 21(3), 131-151.

Lee, S. H. (2014). The effects of children's perception of mother's responses to negative emotions and ego resilience on their life satisfaction (Unpublished master's thesis). Chonnam National University, Gwangju, Korea.

Lee, S. J. (2006). The relationships among the emotional clarity, cognitive emotion regulation and mental health (Unpublished master's thesis). Chung-Ang University, Korea.

Lee, Y. K. (2012). The mediating effects of self-esteem and self-efficacy in the relationship between social support and youth leadership life skills (Unpublished doctoral dissertation). Myongji University, Seoul, Korea.

Lempers, J. D., Clark-Lempers, D., \& Simons, R. L. (1989). Economic hard ship, parenting, and distress in adolescence. Child Development, 60(1), 25-39.

Li, B., Ma, H., Guo, Y., Xu, F., Yu, F., \& Zhou, Z. (2014). Positive psychological capital: A new approach to social support and subjective well-being. Journal of Social Behavior and Personality, 42(1), 135-144. doi:http://dx.doi.org/10.2224/sbp.2014.42.1.135

Lim, D. S. (2011). The mediating effects of optimism on the relationships between parental attachment and emotional regulation (Unpublished master's thesis). Dongshin University, Naju, Korea.

Lim, J. H., \& Moon, J. Y. (2012). Temperament and social support in relation to hope of institutionalized children. Journal of Korean Child Care and Education, 8(2), 63-80.

Luthans, F. (2002). The need for and meaning of positive organizational behavior. Journal of Organizational Behavior, 23(6), 695-706. 
Luthans, F., Avolio, B. J., Avey, J. B., \& Norman, S. M. (2007). Positive psychological capital: Measurement and relationship with performance and satisfaction. Personnel Psychology, 60(3), 541-572.

Luthans, F., \& Youssef, C. M. (2004). Human, social, and now positive psychological capital management: Investing in people for competitive advantage, Organizational Dynamics, 33(2), 143-160.

Luthans, F., \& Youssef, C. M. (2007). Emerging positive organizational behavior, Journal of Management, 33(3), 321-349.

Luthans, F., Youssef, C. M., \& Avolio, B. J. (2007). Psychological capital: Developing the human competitive edge. Oxford, U. K.: Oxford University Press.

Martin, R. A., Kuiper, N. A., Olinger, L., \& Dance, K. A.(1993). Humor, coping with stress, self-concept, and psychological well-being. HUMOR: International Journal of Humor Research, 6(1), 89-104.

Mayer, J. D., \& Salovey, P. (1990). Emotional intelligence. Imagination, Cognition and Personality, 9(3), 185-211.

Min, B. B., Oh, H. S., \& Lee, J. Y. (2007). Temperament and Character Inventory-family manual. Seoul: Maumsarang.

Ministry of Health, Welfare and Family Affairs. (2015). Korea youth risk behavior web-based survey. Daejeon, Korea: Statistics korea.

Moafian, F., \& Ghanizadeh, A. (2009). The relationship between Iranian EFL teacher's emotional intelligence and their selfefficacy in language institutes. System, 37(4), 708-814.

Moon, H. R., \& Lee, D. H. (2015). Relationship of mothers' parenting attitudes and female teachers' discipline styles perceived by children and their empathy and hope. Journal of Educational Innovation Research, 25(2), 113-132.

Moon, Y. L. (1999). The development of emotion intelligence program for moral character education. Seoul National University Education Collection of Treatises, 59, 31-98.

Multon, K. D., Brown, S. D., \& Lent, R. W. (1991). Relation of self-efficacy beliersto academic outcomes: A meta-analytic investigation. Journal of Counseling Psychology, 38(1), 3038.

Myeong, S. J. (2011). The effects of social support, academic achievement, and optimism on middle school students' happiness (Unpublished doctoral dissertation). Kangwon National University, Chuncheon, Korea.

Myeong, S. J., \& Kang S. H. (2011). The effects of social support, academic achievement, and optimism on middle school students' happiness. Journal of Educational Evaluation, 24(3), 619-643.

No, J. Y. (2004). The relation between family function and hope in adolescents (Unpublished master's thesis). Gyeongsang National University, Changwon, Gyeongnam, Korea.
Noh, H. E., \& Park, K. J. (2001). Relationships between perceived parental child-rearing practices and self-efficacy for adolescents. Journal of Yonsei University, 49, 55-71.

Oh, S. O. (2006). The relationship between social support and subjective well in mediating effects of emotion regulation (Unpublished master's thesis). Korea University, Seoul, Korea.

Park, J. G. (2002). On the relation of parents' child-rearing attitudes perceived by middle school students, achievement motivation and self-efficacy (Unpublished master's thesis). Sogang University, Seoul, Korea.

Park, J. S. (2009). Social support perceived by children and their egoresilience (Unpublished master's thesis). Inha University, Incheon, Korea.

Park, S. Y. (2013). Relationships of depression and positive emotions with hope and the mediating and moderating role of family support for people in low-income. Korean Journal of Family Social Work, 40, 189-214.

Park, Y. M. (2010). The effects of children from low income families' perceived social support on ego-resiliency and sociability: Focused on community child center (Unpublished master's thesis). Myongji University, Seoul, Korea.

Parker, S. K. (1998). Enhancing role breadth self-efficacy: The role of job enrichment and other organizational interventions, Journal of Applied Psychology, 83(6), 835-852.

Peterson, C., \& Bossio, L. M. (1991). Health and optimism. New York, NY: Free press.

Pyun, J. Y. (2012). Cognitive biases of high harm avoidance people: Focusing on self efficacy (Unpublished master's thesis). Seoul University, Seoul, Korea.

Rutter, M. (1987). Psychosocial resilience and protective mechanism. American Journal of Orthopsychiatry, 57(3), 316-331.

Salovey, P. (1997). Emotional development and emotional intelligence: Educational implication. New York, NY: Basic Books.

Salovey, P., \& Mayer, J. D.(1990). Emotional intelligence. Imagination, Cognition and Personality, 9(3), 185-211.

Scheier, M. F., \& Carver, C. S. (1985). Optimism, coping and health: Assessment and implications of generalized outcome expectancies. Health Psychology, 4(3), 219-247.

Scheier, M. F., \& Carver, C. S. (1992). Effects of optimism on psychological and physical well-being: Theoretical overview and empirical update. Cognitive Therapy and Research, 16(2), 201-228.

Seligman, M. E. P. (1998). Learned optimism how to change your mind and your life. New York, NY: Vintage books.

Shin, H. S., \& Jang, Y. O. (2001). The effects of perceived parentsadolescent communication style on adolescent's selfefficacy. Journal of Korean Home Management Association, 19(5), 189-202. 
Shin, S. Y. (2006). The relationship between school-adjustment, coping types of stress and self-efficacy in middle school student (Unpublished master's thesis). Kyungnam University, Changwon, Gyeongnam, Korea.

Shorney, H. S., Snyder, D. R., Yang, X., \& Lewin, M. R. (2003). The role of hope as a mediator in recollected parenting, adult attachment, and mental health. Journal of Social and Clinical Psychology, 22(6), 685-715.

Snyder, C. R., Sympson, S. C., Ybasco, F. C., Borders, T. F., Babyak, M. A., \& Higgins, R. L. (1996). Development and validation of the state hope scale. Journal of Personality and Social Psychology, 70(2), 321-335.

Son, S. H. (2014). Effects of young children's temperament and maternal parenting attitude on young children's optimism: $A$ mediating effect of mother's emotional expression (Unpublished doctoral dissertation). Keimyoung University, Daegu, Korea.

Song, J. Y. (2010). What does lead students to adopt approach or avoidance goal in the face of failure?: The role of temperaments, self-efficacy, theory of intelligence, controllability, and shame (Unpublished master's thesis). Korea University, Seoul, Korea.

Sung, Y. H. (1993). A study on relationships between parent's supportive systems and the childrens' behavioral problems (Unpublished Doctoral dissertation). Ewha Womans University, Seoul, Korea.

Tugade, M. M., \& Fedrickson, B. L. (2004). Resilient individuals use positive emotion to bounce back from negative emotional experiences. Personality and social psychology, 86(2), 320-333.

Wagnild, G. M., \& Young, H. M. (1993). Development and psychometric evaluation of the resilience scale. Journal of
Nursing Management, 1(2), 165-178.

Yang, S. Y. (2015). Effects of mother's optimism, happiness and affective parenting on children's optimism and happiness (Unpublished master's thesis). Chungbuk University, Cheongju, Chungbuk, Korea.

Yeo, I. J. (2015). The effects of social support and emotional regulation on customer orientation-focusing on the mediating effects of positive psychological capital (Unpublished Doctoral dissertation). Kyonggi University, Suwon, Gyeonggi, Korea.

Yoon, H. J. (1993). A perception of everyday stress and social network support in adolescence (Unpublished doctoral dissertation). Seoul University, Seoul, Korea.

Yoon, Y. J. (2012). An analysis of the relationships between parentadolescent communication and ego-resiliency, anger, angercontrol, and depression of middle school students (Unpublished master's thesis). Keimyung University, Daegu, Korea.

You, J. H. (2013). The relationship between emotional intelligence and subjective career success of employees: The mediating effect of general self-efficacy (Unpublished master's thesis). Sungkyunkwan University, Seoul, Korea.

\section{ORCID}

Ara Choi http://orcid.org/0000-0001-9780-8564

Sook Lee http://orcid.org/0000-0002-0719-689X

Received February 15, 2016

Revision received April 12, 2016

Accepted April 20, 2016 